\title{
Yaşam Boyu Toplumsal Cinsiyet Rollerinin Gelişimi
}

\section{Lifespan Development of Gender Roles}

\author{
Bahar Bahtiyar Saygan¹ (D), Nilay Pekel Uludağ|² (D)
}

\begin{abstract}
Öz
Günümüzde hemen hemen her çocuk, cinsiyet rollerinin sosyal olarak inşa edildiği bir topluma doğmakta ve bu roller bazında ayrıştııımış bir dünyada büyümektedir. Bebeklik ve çocukluk dönemi boyunca sosyalleştirme sürecinde rol oynayan aile, arkadaş, medya gibi faktörlerin etkisiyle çocuklar, toplum tarafindan belirlenen ve uyum göstermeleri beklenen cinsiyet rollerini öğrenmektedir. Bu doğrultuda cinsiyet farklılıklarına bakıldığında, kız çocukları daha baskıı yaklaşımlarla karşılaşmakta ve onların, oğlan çocuklarına göre daha uysal, boyun eğen, uyumlu, duygularını gösteren, iliskilere önem veren bir biçimde davranmaları istenmektedir. Öte yandan oğlan çocukları ise baskın, güçlü, bağımsız ve duygu kontrolüne sahip olarak yetiştirilmekte ve her koşulda bu doğrultuda davranmaları beklenmektedir. Bebeklikten ergenliğe bu öğretilerle sosyalleştirilen çocuklar, kendi ebeveynlerinin sergilediği cinsiyet rollerinden de güçlü bir şekilde etkilenerek, toplumsal cinsiyet rollerini içselleştirmektedir. İçselleştirilmiş bu cinsiyet rollerinin etkisi yaşam boyu sürmektedir. Cinsiyet kalıpyargılarııın hem kadınlar hem de erkekler üzerinde kısa ve uzun vadede baskı ve strese neden olduğu bilinmekte, toplumun cinsiyet bazlı beklentilerine uyum gösterme ihtiyacı bireylerin psikolojik sağlğını olumsuz yönde etkilemektedir. Son yıllarda cinsiyet eşitliği konusunda toplumsal farkındalık artsa da halen birçok ülkede pek çok alanda cinsiyet eşitsizliğinin sürdüğü bilinmektedir. Sonuç olarak, ilgili alan yazında tutarlı bir şekilde belirtildiği gibi, toplumsal cinsiyet psikolojisi her iki cinsiyeti de yaşamlarının her döneminde etkilemekte ve bu da cinsiyet eşitliğine yönelik politikaları önemini açıça ortaya koymaktadır.
\end{abstract}

Anahtar sözcükler: Cinsiyet gelişimi, cinsiyet rolleri, cinsiyet kalıpyarglları, cinsiyet eşitliği, yaşam boyu gelişim

\section{Abstract}

Today, almost every child is born into a society where gender roles are socially built and grows in such a gender-segregated world. With the influence of factors such as family, friends, and media, which play a role in the socialization process during infancy and childhood, children learn about gender roles determined by the society. In this context, from the perspective of gender differences, girls face more oppressive approaches and are expected to behave submissively, be more easy going, complier, relational, and show their emotions more deeply compared to their male peers. On the other hand, boys are rared as strong, independent, less emotional, and they are expected to behave in this way under all circumstances. Children who are socialized with these teachings from infancy to adolescence are also strongly influenced by the gender roles displayed by their parents and ultimately internalize those gender roles which has a lifetime effect on them. It is known that gender stereotypes cause pressure and stress on both women and men both concurrently and in the long-run, and the need to adapt to the gender-based expectations of the society adversely affects their psychological health. Although social consciousness about gender equality has increased in recent years, it is known that gender inequality still continues in many countries. As a result, psychology of gender affects each individual at every stage of their lives, as stated consistently in the related literature, which clearly demonstrates the importance of policies for gender equality.

Keywords: Gender development, gender roles, gender streotypes, gender equality, lifespan development

\footnotetext{
1 Atllım Üniversitesi, Ankara, Türkiye

2Acıbadem Üniversitesi, İstanbul, Türkiye

$凶$ Nilay Pekel Uludağlı, Acıbadem Üniversitesi, Psikoloji Bölümü, İstanbul, Türkiye npuludagli@gmail.com | 0000-0002-3886-1821
}

Geliş tarihi/Received: 02.09.2020 | Kabul tarihi/Accepted: 21.09.2020| Çevrimiçi yayın/Published online: 20.12.2020 
HAYATLARININ ilk yıllarından itibaren çocuklar, kültürlerine özgü cinsiyet rollerine yönelik pek çok kalıpyargıya maruz kalarak, bunları benimsemeye ve bu yönde davranmaya başlamaktadır. "Oyuncak bebek-araba" ve/veya "evcilik-tamircilik" oyunları gibi ikilemelerin, akla "kız çocuğu-oğlan çocuğu" cinsiyet ayrımını getiriyor olması (Blakemore ve Centers 2005), toplumsal cinsiyet rollerinin çocukluk döneminden itibaren algılanan etkisini ortaya koymaktadır. Bu etkiler sadece yaşamın ilk yıllarıyla sınırlı kalmamakta, yetişkinlik ve yaşl1lı dönemi olmak üzere sonraki gelişimsel dönemlerde de bireyin iyi oluş hali üzerinde önemli bir rol oynamaktadır (Pinquart ve Sörensen 2001). Bu bağlamda, toplumsal cinsiyet psikolojisine ilişkin bu gözden geçirme yazısında cinsiyetin doğum öncesinden yaşlilığa yaşam boyu birey ve sosyal ilişkileri üzerindeki etkileri ilgili alanyazın kapsamında ele alınacaktır.

Toplumsal cinsiyet rollerinin çocuk gelişimi -ve dolayısıyla yaşam boyu birey psikolojisiüzerindeki etkileri, bu alanda özellikle 1970'li yıllar itibariyle yaygın olarak araştırılmaya başlanmıştır (Money 1973, Thompson 1975). Bu noktada, bebeklik ve çocukluk dönemi toplumsal cinsiyet rollerini daha iyi anlamlandırabilmek için, ilgili kavramların kısaca tanımlanması yerinde olacaktır. Cinsiyet kalıpyargıları (gender stereotypes), kız çocuklar ve oğlan çocukları için uygun görülen özellikler hakkında yaygınlıkla kabul edilen inanışlardır (Ruble ve Martin 1998). Cinsiyet rolleri (gender roles), bu kalıpyargıların günlük hayatta davranışlara yansıma şekilleridir (Basow 2006). Cinsiyet kimliği (gender identity), kişinin kendisini hangi cinsiyette tanımladığı/hissettiği ile ilişkili benlik/kendilik algısı olup, kişinin biyolojik/atanan cinsiyeti ile uyumlu veya uyumsuz olabilmektedir (Basow 2006). Cinsiyet tiplemesi (gender typing), bireylerin sergilediği aktivite, davranış, rol veya kişisel özelliklerin belirli bir biyolojik cinsiyetle ilişkilendirilmesi olarak tanımlanmaktadır (Martin ve Dinella 2001). Son olarak, cinsel yönelim (sexual orientation), kişinin cinsel ve romantik olarak hangi cinsiyete çekim duyduğunun ifadesidir (Sell 1997).

Cinsiyet tiplemelerinin çeşitli öğelerini -cinsiyet kalıpyargıları ve cinsiyet rolleri kazanımı gibi- birlikte ele alarak, çocuklarda "erkeksi” veya "kadınsı" olarak nitelendirilen cinsiyet ifadelerinin ortaya çıkması ve bunların çocuklar tarafından zaman içinde güçlü bir şekilde kanıksanması, çoğunlukla cinsiyet şemaları üzerinden açıklanmaktadır (Martin ve Halverson 1981). Bu bağlamda çocuklar, hayatlarının ilk yıllarından itibaren, çevrelerindeki bireylerin cinsiyetle ilişkilendirilen davranışlarını gözlemlerler, bu deneyimleri zihinlerinde organize ederek cinsiyet şemaları/sınıflandırmaları elde ederler ve dünyayı zihinlerinde oluşan bu şemalar çerçevesinde değerlendirirler. "Sadece erkekler doktor olabilir" veya "yemek pişirmek kadınların işidir” gibi cinsiyet şemalarının oluşmasının ardından ise çocuklar, kendilerini ve yeni edindikleri bilgileri, bu şemalar doğrultusunda kategorize etme ve davranışlarını bu yönde belirleme eğiliminde olurlar (Liben ve Bigler 2002). Cinsiyet şemaları çocukların zihinlerine oldukça güçlü şekilde yerleşirler; öyle ki, toplumsal cinsiyet rollerine uygun olmayan davranışları hatırlayamama veya bilişsel çarpitmalar yaparak hatırlama gibi davranışlar (örn., çocuklara erkek hemşire fotoğrafi gösterilmesinden bir süre sonra fotoğrafını gördükleri kişiyi tanımlamaları istediğinde, erkek bireyi hemşire değil doktor şeklinde hatırlamaları) gözlemlenebilmektedir (Liben ve Signorella 1993, Martin ve 
Ruble 2004). Buna karşın, erken yaşlarda oluşan cinsiyet şemalarını özellikle okul yaşlarında verilebilecek eğitimlerle değiştirmek mümkün olabilmektedir. Bigler ve Liben’in (1992) belirttiği gibi, okul yaşlarında hızla gelişen bilişsel yetilerin de etkisiyle, toplumsal cinsiyet rollerini reddeden nitelikteki sosyal mesajların, çocukların zihinlerindeki kalıplaşmış cinsiyet şemalarını esnek bir hale getirebildiği; bir kişinin cinsiyetinin değil, yetenek ve ilgisinin bir aktiviteyi ne kadar iyi yapabileceğini belirlediği öğretildiğinde, cinsiyet rollerinin "değişmezliğ̣i” fikrinden uzaklaştıkları, çok daha eşitlikçi düşünebildikleri bilinmektedir.

$\mathrm{Bu}$ bağlamda bireylerin, erken yaşlardan itibaren cinsiyet kalıpyargılarına yönelik farkındalıklarını artırarak cinsiyet eşitliği temelinde sosyalleştirilmeleri, daha sağlıklı benlik algısı ve kişiler arası ilişkiler için oldukça önemlidir (Turner ve Gervai 1995, King ve ark. 2020). Ülkemizde bu konudaki farkındalığı artırmaya yönelik bazı çalışmalar olmakla birlikte, bu çalışmalarda genellikle kadınlar açısından toplumsal cinsiyet eşitliğine odaklanılmıştır (Davas-Aksan ve ark. 2011, Demirdirek ve Şener 2014, Evrenol-Öçal 2019). Özellikle erken çocukluk döneminde toplumsal cinsiyet eşitliği konusunda müdahale çalışmaları oldukça sınırlıdır (Temiz ve Cin 2017, Tuncer ve Gezer-Şen 2018). Ülkemizde her iki cinsiyet açısından toplumsal cinsiyet rollerinin etkilerini erken yıllardan ileri yaşa kadar bir arada değerlendiren bir çalışma bulunmamaktadır. Bu gözden geçirme yazısı ile toplumsal cinsiyet rollerinin, sadece erken yıllar değil tüm yaşam üzerindeki etkilerini bütüncül bir yaklaşımla ortaya koyabilmek için doğum öncesi ve bebeklik döneminden yaşlılık dönemine kadar, toplumsal cinsiyet rollerinin bireyin yaşamını nasıl şekillendirdiği tüm gelişim dönemlerinde sırayla ele alınacaktır.

\section{Doğum öncesi, bebeklik ve erken çocukluk}

Toplumsal cinsiyet rolleri üzerine yapılan araştırmalar, cinsiyet tiplemelerinin sebepleri üzerine yoğunlaşmak amacıyla doğum öncesi ve bebeklikten başlayıp yaşlılığa kadar tüm gelişimsel süreçlerde olmak üzere, genellikle davranışa (cinsiyetler arası davranışsal benzerlik veya farklılıklara) odaklanmaktadır. Daha temele inildiğinde ise, hormon çalışmaları görülmekte ve bu kapsamda yürütülen çalı̧̧malar, "Doğumsal Adrenal Hiperplazi” adıyla bilinen genetik bozukluğu ön plana almakta, bu bozukluğun adrenal sistemdeki androjen düzeyinin doğum öncesi süreçten itibaren olağanüstü yüksek seviyelerde üretilmesine sebep olduğu bilinmektedir. Bu genetik bozukluğa sahip hastalarla yürütülen çalışmalar ise, androjenin -her iki cinste de bulunan bir hormon olmasına rağmen- "erkeksi" olarak nitelendirilen davranışlarla ilişkili olduğunu, özellikle bu bozukluğa sahip kadınların çocukluk dönemlerinde "kadınsı" kimliklerinden (Hines ve ark. 2004) ve bu yöndeki oyun dayatmalarından hoşnut olmadıklarını hatırladıkları rapor edilmiştir (Servin ve ark. 2003, Hall ve ark. 2004). Bu bulgu ile paralel olarak Auyeung ve arkadaşları (2009) da, Doğumsal Adrenal Hiperplazi sebebiyle doğum öncesi yüksek oranda androjene maruz kalan kız çocuklarının, yüksek düzeyde "erkeksi" olarak nitelendirilen davranış sergiledikleri ve oyun tercihlerini de bu yönde yaptıklarını gözlemlemişlerdir. Öte yandan hayvanlarla yapılan deneyler de benzer şekilde, doğum öncesi uygulanan androjenin hem dişi hem de erkek memelilerde aktif oyunu ve saldırgan davranışları artırdığını, bakım verme davranışını ise 
azalttığını göstermiştir (Lephart ve ark. 2001, Sato ve ark. 2004).

Maccoby (1998), hayvan araştırmalarıyla bulunan hormon etkilerinin kısmen de olsa insanlara genellenebileceğini öne sürmüştür. Oyun yaşına gelmesinden itibaren hemcinsi akranlarıla oynamayı tercih eden çocuk davranışının, diğer pek çok memeli türün yavrularında da görüldüğünü gösteren çalışmalar bu bilgiyi destelemektedir (Beatty 1992, Munroe ve Romney 2006). Bu tercih, yaş ilerledikçe çocukların cinsiyet kimliklerini keşfetmeye ve cinsiyetin değişmezliğini kavramaya başlamalarıyla beraber daha belirgin hale gelmektedir. Çocuklar, dört yaşlarına geldiklerinde hemcinsleriyle -karşı cins yaşıtlarına kıyasla- üç kat daha fazla zaman geçirmekte, altı yaşlarında ise bu oran 1/11'e kadar yükselmektedir (Martin ve Fabes 2001, Mehta ve Strough 2010). Böylelikle çocuklar, çoğunlukla hemcins akranlarıyla kendi cinsiyetlerine atfedilen normlar ve davranış stilleri üzerinden sosyalleşerek, bu norm ve davranış stilleri çerçevesinde kendilerini daha rahat hissetmekte, bunun sonucu olarak da -bir kısır döngüye dönüşen şekilde- çoğunlukla yine hemcinsleriyle vakit geçirmeyi tercih etmektedir (Martin ve ark. 2011). Bu kısır döngünün kaçınılmaz sonucu olarak ise, karma bir grup içerisinde oyun oynamaları veya bir proje üzerinde birlikte çalışmaları istenen okulöncesi ve okul çağındaki çocukların, karşı cins akranlarıyla çok daha az iş birliği yaptıkları, sözel ve davranışsal açıdan daha negatif tavırlar sergiledikleri gözlemlenmiştir (Holmes-Lonergan 2003, Leaper ve Smith 2004, Leman ve ark. 2005). Cinsiyet farklılıklarının birtakım biyolojik temellerinin olduğu bilinse de, çevresel deneyimlerin biyolojik bazlı cinsiyet farklılıkları üzerinde etkisi olduğu da bilinmektedir (Ruble ve ark. 2006). Güncel araştırmalar, cinsiyet farklılıkları üzerinde sosyal baskının etkisini de kanıtlar niteliktedir. Toplumsal cinsiyet rollerine uygun şekilde davranarak; hemcins yaşıtlarını daha olumlu değerlendirme ve karşıt cinsten olanlara yönelik daha olumsuz beklentiler içine girme, çocukların cinsiyet kalıpyargılarını etkileyerek oyun ve sosyal ilişki tercihleri üzerinde belirleyici rol oynamaktadır (Ruble ve ark. 2006).

Çocuklar, 18 ile 30 ayları arasında hem kendilerinin hem de çevrelerindeki insanların cinsiyetlerini tanımlayabilir hale gelmektedir. Ancak bu yaşlarda, cinsiyetin biyolojik temelli oluşu ve değişmezliği bilgisine sahip değillerdir (Sravanti ve Sagar 2019). Örneğin, kız çocuklarına sorulan "Büyüdüğünde baba olabilir misin?” veya "İsteseydin oğlan çocuğu olabilir miydin?” gibi sorulara çoğunlukla "evet” şeklinde yanıt vermektedirler (Slaby ve Frey 1975). Benzer şekilde, bu yaşlarda, kız bebek görünümlü oyuncaklarının veya tanıdıkları oğlan arkadaşlarının saç stilleri ve kıyafetleri değiştirilip gösterildiğinde, cinsiyetlerinin değiştiğine inandıklarını belirten çalışmalar bulunmaktadır (Fagot 1985, Chauhan ve ark. 2005). Çocuklar, 5-7 yaşlarına geldiklerinde ise bilişsel gelişimleriyle de paralel olarak, cinsiyetin biyolojik temelleri olduğunu, karşı cinsle ilişkilendirdikleri özellikleri (örn., kısa/uzun saçlı olmak, pantolon/etek giymek vs.) görseler dahi, cinsiyetin sabit kaldığını anlayabilir hale gelmektedirler (Emmerich 1981, Ruble ve ark. 2007).

Bunların yanı sıra, çocuklar henüz 2 yaşlarına gelmeye başlarken de, kadın ve erkekleri toplumsal cinsiyet rollerine göre ayırt edebilmektedir. Pek çok araştırmacı, özellikle okul öncesi yaşta (3-6 yaş) çocukların; oyuncakları, kıyafetleri, malzemeleri, evle ilgili nesneleri, oyunları, meslekleri, renkleri (örn., pembe ve mavi) ve davranı̧̧ları (örn., ilişkisel veya 
fiziksel öfke), cinsiyetlerden biri ile ilişkilendirdiklerini bulmuşlardır (Poulin-Dubois ve ark. 2002, Giles ve Heyman 2005, Ruble ve ark. 2006). Benzer şekilde, "ayılar oğlanlar içindir”, "kelebekler kızlar içindir” gibi cinsiyet kalıpyargılarını ortaya koyan eşleştirmeler yaptıkları da bulunmuştur (Leinbach ve ark. 1997). Erken çocukluk dönemindeki bu cinsiyet kalıpyargılarının oldukça güçlü ve esneklikten uzak olduğu gözlemlenmektedir. Blakemore'un (2003) çalışmasına göre, 3-4 yaş çocuklarına, cinsiyet kalıpyargılarının ihlal edilip edilemeyeceği sorulduğunda, çocukların yarısından fazlasının -özellikle kıyafet, saç stili ve oyuncaklarla ilgili maddelerde- kesin bir ifadeyle "hayır" dedikleri görülmüştür.

Benzer şekilde, 3-6 yaş arası çocukların çoğunluğunun, cinsiyet kalıpyargılarının dışında hareket eden (örn., oje süren oğlan çocukları, kamyonlarla oynayan kız çocukları vb.) akranlarıyla arkadaş olmak istemedikleri rapor edilmiştir (Ruble ve ark. 2007). Okul öncesi yaşlardaki çocukların cinsiyet kalıpyargılarına yönelik sergiledikleri bu katı duruşun bir sebebi, çevrelerinde sürekli olarak cinsiyetçi tutum ve davranışlara maruz kalmaları, dolayısıyla bu davranışları model alarak "doğru" davranışların yalnızca bunlar olduğunu düşünmeleridir. Bir diğer sebebi ise, henüz bilişsel gelişimlerini tamamlamamış olmaları dolayısıyla, başkalarının kendilerinden farklı düşünce sistemlerine sahip olabileceğini anlama becerilerinin henüz gelişmemiş olmasıdır (Berk 2017). Bu sebeple de okul öncesi yaşlardaki çocuklar, başta aile bireyleri olmak üzere çevrelerindeki insanlar tarafindan "kadınsı" veya "erkeksi” olarak nitelendirilen davranış, aktivite, oyuncak, meslek, saç stili veya kıyafetlerin, bir kişinin cinsiyetini belirleyemeyeceğini, kadın ve erkeklerin görünüş olarak farklı olsalar da pek çok farklı alanda birbirlerine benzemelerinin ve benzer aktiviteler yapabilmelerinin normal olduğunu anlamakta güçlük çekebilmektedir. Dolayısıyla, okulöncesi yaştaki çocuklar cinsiyet kavramı hakkında hem daha düşük düzeyde bilgi sahibi olmaları hem de bilişsel kısıtlılıklarının etkisiyle, cinsiyet kalıpyargıları doğrultusunda davranma ve gözlemledikleri davranışlarını bu çerçevede değerlendirme eğilimi göstermektedir (Sravanti ve Sagar 2019).

\section{Orta çocukluk}

Çocuklar okul çağına geldiklerinde, cinsiyet kalıpyargılarına yönelik düşünceleri ve inanışları daha esnek hale gelebilmekle birlikte, ebeveynleri ve içinde yaşadıkları kültür, çocukların cinsiyet kalıpyargılarını pekiştirmeye devam etmektedir. Örneğin, sözel ve sanatsal ağırlıklı alanlarda kız çocuklar daha yetkin görülürken; sayısal -özellikle matematik- ve spor faaliyetleri alanlarında da oğlan çocukları daha yetkin görülmektedir (Eccles ve ark. 1990, Jacobs ve Weisz 1994). Maruz kaldıkları bu cinsiyet kalıpyargıları, karşılaştırılan alanlardaki yeterlilikleri ölçüldüğünde gerçek anlamda bir cinsiyet farkı bulunmamasına rağmen, çocukların benlik yeterliliklerini (kendilerini yeterli algılama düzeylerini) güçlü bir şekilde etkilemektedir (Freedman-Doan ve ark. 2000, Hong ve ark. 2003, Bhanot ve Jovanovic 2005). Avrupa'nın çeşitli ülkeleri ile Japonya, Rusya ve Amerika'da yaşayan 2000'den fazla çocukla (8-12 yaşları arası) yürütülen bir çalışmada, kız çocuklarının oğlan çocuklarına kıyasla tutarlı şekilde daha yüksek okul puanlarına sahip oldukları görülmüş; ancak buna rağmen kız çocukları, oğlan çocuklarını kendilerine oranla daha "akıllı" olarak değerlendirmişler, kendi başarılarını azımsamışlardır (Stetsenko ve ark. 2000). Bu bulgu, hem ebeveynler hem de 
öğretmenlerin, kız çocuklarının başarısızlıklarında onların kendi yetersizliklerine atıf yapıp, oğlan çocuklarının başarısızlıklarını dışsal faktörlere bağlamaları bilgisiyle örtüşmektedir (Pomerantz ve Dong 2006). Bu durum her ne kadar kültürler arası farklılıklar gösterebilse de, kız çocuklarının algılanan dezavantajlı pozisyonuyla pek çok kültürde yaygın şekilde karşılaşılmaktadır. Kültür etkisinin yanı sıra, ailelerin eğitim ve sosyoekonomik düzeylerinin de, çocuklarının benimsediği toplumsal cinsiyet rolleri üzerine etkisi olduğu bilinmektedir. Yüksek eğitim düzeyi ve sosyoekonomik düzeye sahip ebeveynlerin çocuklarının, geleneksel cinsiyet kalıpyargıları konusunda daha esnek olduğu bulunmuştur (Lackey 1989, Serbin ve ark. 1993).

Okul çağı çocuklarının akademik yeterlilikleri ve başarılarına yönelik ebeveynlerinin beklentilerinin de, genellikle geleneksel kalıpyargılar çerçevesinde olduğu görülmektedir. Eccles ve arkadaşları (2000) tarafından yürütülen, annelerden altıncı sınıf çocuklarının matematikteki yeterliliklerini değerlendirmeleri istenen çalışmanın bulgularına göre anneler, -çocuklarının matematik konusundaki gerçek yeterliliklerinin ne olduğundan bağımsız şekilde- oğlan çocuklarının kız çocuklarına kıyasla daha yeterli olduğunu rapor etmişlerdir. Annelerin bu algısı, sözel veya sözel olmayan mesajlar aracılığıyla çocuklara yansımakta ve bu mesajlar çocukların kendilerine yönelik algılarını ve bu algı çerçevesinde de performanslarını etkilemektedir. Nosek ve arkadaşlarının (2009) 34 ülkeyi karşılaştırdıkları kültürler-arası çalışmasına bakıldığında ise, cinsiyet kalıpyargılarının daha baskın şekilde kabul gördüğü kültürlerde, cinsiyetler arası matematik başarısı farkı -kız çocuklarının aleyhine- daha yüksek olarak bulunmuştur. Bu durum, beklenen şekilde, kız çocuklarının matematiğe yönelik ilgisini, çalı̧̧ma isteğini, motivasyonunu ve özgüvenini olumsuz yönde etkilemekte, düşük matematik performansı da bu durumu kaçınılmaz şekilde takip etmektedir (Steffens ve ark. 2010). Benzer şekilde, Tenenbaum ve Leaper'in (2003) çalışması kapsamında, anne ve babalarıyla bilim müzesi gezen 11-13 yaş kız ve oğlan çocuklarının sohbetleri incelenmiştir. $\mathrm{Bu}$ inceleme sonucunda, başlangıçta çocukların bilime yönelik ilgileri, bilimle alakalı derslerdeki notları ve bu konudaki benlik yeterlilikleri arasında herhangi bir cinsiyet farkı bulunmamasına rağmen, ebeveynlerin kız çocuklarının bilimi daha zor bulduğu ve bilime olan ilgilerinin daha az olduğuna inandıkları görülmüş; bu bağlamda da, ebeveynlerin kız çocuklarıyla -oğlan çocuklarına kıyasla- bilimsel konuları daha az ve basit bir dille konuştukları saptanmıştır. Bu çerçeveden bakıldığında cinsiyet ayrımlarının, hayatın başından itibaren maruz kalınan kalıpyargıların etkisiyle ortaya çıkabildiği, güçlenerek benimsendiği ve özellikle de toplumun ve ebeveynlerin tutum ve davranışlarına bağlı olarak kanıksanarak sürdüğü sonucuna varılabilmektedir.

Öte yandan, oğlan çocuklarının ise cinsiyet kalıpyargılarının ihlali (başka bir ifadeyle, karşı cinsiyet davranışı -cross-gender behavior- sergileme) konusunda kız çocuklarına kıyasla daha dezavantajlı durumda olabildikleri görülmektedir. Blakemore’un (2003) çalışmasına göre, hem kız hem oğlan çocukları tarafindan; oğlan çocuklarının oyuncak bebekle oynaması, kız çocuklarının kamyonla oynamasına kıyasla daha olumsuz şekilde değerlendirilmektedir. Benzer şekilde, oğlan çocukları da, erkeklere yönelik "olması beklenen” cinsiyet rollerine daha güçlü şekilde uyum göstermektedirler (Bussey ve Bandura 1992, Ruble ve ark. 2006). 
Çocukların yanı sıra, ebeveynlerin bu konudaki bakış açılarını inceleyen Turner ve Gervai (1995) ise, yine benzer şekilde ebeveynlerin de karşı cinsiyet davranışına yönelik tutumlarının oğlan çocukları söz konusu olduğunda -kız çocuklarına kıyasla- çok daha negatif olduğunu göstermiştir. Dolayısıyla cinsiyet kalıpyargılarına uygun şekilde davranma konusunda oğlan çocuklarının üzerindeki sosyal baskı, kız çocuklara oranla daha fazla olabilmektedir (Levy ve ark. 1995, Egan ve Perry 2001, Leaper 2013).

Çocukluk döneminde toplumsal cinsiyet rollerine uyma davranışını belirleyen faktörler arasında, ebeveynlerin cinsiyet rolleri ile alakalı davranışlarını model alma ve onların beklentilerini karşılama isteği olduğu bilinmektedir (Berk 2017). Dolayısıyla çocuklarda, bu beklentilere uygun oyun ve arkadaş seçimleri, fiziksel görünüme yönelik çevresel kaynaklı istekler, davranı̧s stilleri ve hatta hedefler/hayaller belirleme görülmektedir (Stern ve Karraker 1989, Vogel ve ark. 1991). Toplumsal cinsiyet rolleri, ebeveynler tarafindan çocuklara direkt sözel ifadelerle (örn., "kız çocukları uslu olur.", "oğlan çocukları ağlamaz." vs.) aktarılabildiği gibi, örtük mesajlar aracılığıyla da aktarılabilmektedir (Mesman ve Groeneveld 2018). Bu örtük mesajlar, genellikle, çocuklara cinsiyet bazlı farklı davranışlarda bulunmak, başka insanlara yapılan cinsiyet ayrımına veya belli davranışların cinsiyete atfedilen değerlendirmelerine çocuğun maruz kalması gibi formlarda olabilmektedir. Bu bağlamda, ebeveynler tarafından açık veya örtük mesajlar aracılığıyla çocuğa aktarılan cinsiyet kalıpyargıları, cinsiyet eşitsizliğini çocuğun zihninde pekiştirmekte, sonuçları da bu doğrultuda derinleşmektedir. Örneğin, cinsiyet kalıpyargılarına maruz kalıp bu kalıpyargılara uyum gösterme davranışı yüksek olan kız çocuklarında, fiziksel görünümle ilgili yüksek düzeyde kayg1 görülmüştür (Halim ve ark. 2018). Ebeveyn ve çevre etkisinin toplumsal cinsiyet rolleri üzerindeki gücü, genellikle çocuk henüz anne karnındayken sinyallerini vermeye başlamaktadır. Bebeğin cinsiyetinin öğrenilmesi itibariyle hazırlanan "pembe veya mavi odalar/kıyafetler" ile başlayan süreç, çocuğun cinsiyetine göre seçilen oyuncaklarla devam etmektedir. Leaper ve Friedman (2007), çocuklara hediye alınan oyuncak türlerini incelediği çalışmasında; oğlan çocuklarına alınan hediyelerin ortak temalarını güç, aktiflik ve yarı̧̧ma/rekabet olarak belirlerken (örn., oyuncak silah/tabanca, arabalar, tamir aletleri, futbol vb. sporlarla ilişkili top vb. oyuncaklar), kız çocuklarına alınan hediyelerin ortak temalarını ise bakım verme, fiziksel çekicilik ve iş birliği (örn., oyuncak bebek, yemek/çay setleri, oyuncak takılar vb.) olarak belirlemiştir. Henüz bebeklik döneminde cinsiyete dayalı tek tip nesne maruziyeti ise, çocukluk döneminde, cinsiyet kalıpyargılarına uygun oyun tercihleri ile olumlu yönde ilişkili bulunmuştur (Lauer ve ark. 2018).

Bunların yanı sıra, farklı kültürlerde yapılan çalışmaların (Fabes ve ark. 2003, Leaper ve Smith 2004) bulgularına göre, kız çocuklarından daha fazla yakınlık davranışı göstermeleri ve ilişkisel olmaları beklenirken, oğlan çocuklarından daha kendinden emin ve özerk olmaları beklenmektedir. Leaper ve arkadaşları (1998) ise, beklenen şekilde, annelerin kız çocuklarıyla -oğlan çocuklarına kıyasla- daha fazla yakınlık davranışı sergilediğini rapor etmişlerdir. Bu bulguları takip eden şekilde ise, kız çocuklarının da hem ebeveynleri hem de arkadaşlarıyla daha yakın ilişkiler kurduğu, daha fazla ilişkisel dil ve duygu kelimesi kullandığı ve daha bağlı (connected) olduğu bulunurken, erkek çocuklarının kendilerini daha 
iddialı şekilde ve kendinden emin bir dil kullanarak ifade ettikleri bulunmuştur (Leaper ve Smith 2004, Tenenbaum ve ark. 2011). Dolayısıla, ebeveynlerin beklentileri çocuklarına karşı sergiledikleri davranışlarını etkilemekte ve bu davranışlar da çocuklar tarafından model alınarak benimsenmekte ve pekişerek sürdürülmektedir (Berk 2017).

Çocuklardaki toplumsal cinsiyet rolleri üzerinde, kardeşler de kuşkusuz önemli bir role sahiptir. Bu rol; kardeş sayısı, sırası, kardeşler arasındaki yaş farkı ve cinsiyetlerinin çeşitli farklılıklarına bağlı olmak üzere değişebilmektedir (McHale ve ark. 2003). Örneğin, büyük kardeşlerin küçük kardeşler üzerinde daha güçlü bir rol model etkisinin olduğu (Farkas ve Leaper 2014); öte yandan, hemcinsi büyük kardeşe sahip çocukların kardeşi olmayanlara kıyasla, kardeşi olmayanların ise karşı cinsten ve kendinden daha büyük kardeşi (örn., oğlan çocukları için abla) olanlara kıyasla geleneksel cinsiyet rollerinin dışına çıkmakta daha çok zorlandıkları görülmüştür (Rust ve ark. 2000). İlgili alanyazın incelendiğinde, cinsiyet gelişimindeki kardeş etkisinin en güçlü ve tutarlı şekilde anlamlı bulunduğu faktörün, büyük kardeşe sahip olmak olduğu görülmekte; bu durum, kardeşlik ilişkilerinde çoğunlukla büyük kardeşlerin "öğretici/örnek olan”, küçük kardeşlerinse "öğrenen/model alan” pozisyonunda olması ile açıklanmaktadır (Stoneman ve ark. 1986). Büyük kardeşlerin, cinsiyetlerinden bağımsız olarak, küçük kardeşlerinin geleneksel cinsiyet rollerine uyum gösterme davranışı üzerinde oldukça etkili olduğu bilinmekte (Rust ve ark. 2000), ancak bu etki tam tersi şekilde de görülebilmektedir. Öyle ki, cinsiyet kalıpyargılarına uygun davranma ihtiyacı hissetmeyen, bu kalıpyargıların dışına çıkabilen, geleneksel toplumsal cinsiyet rollerini reddeden büyük kardeşlerin kız veya oğlan küçük kardeşlerinde de geleneksel cinsiyet rollerine uyum davranışının daha az düzeyde olduğu belirtilmiştir (McHale ve ark. 2001). Kardeşlerin yanı sıra, çocukluk döneminde özellikle okulöncesi yaşlardan itibaren, arkadaş/ akranlar da çocukların cinsiyet gelişimlerinde önemli bir role sahip olabilmektedir (Bigler ve Liben 2007). Cinsiyet bazlı ayrım, seçim, ifade ve davranışların daha belirgin olduğu arkadaş ortamında olan çocukların, bu ortamda vakit geçirdikçe cinsiyet kalıpyargılarında önemli ölçüde artış olduğu, karşı cinsten akranlarına yönelik daha az olumlu değerlendirmeler yaptıkları ve karşı cinsten arkadaşlarıyla oynamayı hemcinslerine göre daha az tercih ettikleri görülürken, cinsiyet kavramının ön planda olmadığı ortamlardaki çocuklarda bu tür eğilimlere rastlanmamıştır (Hilliard ve Liben 2010).

Çocukların toplumsal cinsiyet rollerini öğrenmeleri, özellikle ebeveynler aracılı̆̆ı ile doğrudan maruz kalma şeklinde olabilirken, ebeveynlerin eşitlikçi tutumlara sahip olduğu ve çocuklarına karşı buna uygun şekilde davrandığ 1 durumlarda bile, toplumun bu konudaki baskın rolü ve bu rolün çocuklar üzerindeki etkisi açıkça görülebilmektedir. Bunun en yaygın örneği ise, çocuk kitapları, çizgi filmler, televizyon reklamları veya bilgisayar oyunları gibi çocukların sıklıkla maruz kaldığı yayınlarda karşımıza çıkmakta; bu yayınlarda, cinsiyet rolleri temsillerinin çok büyük oranda, geleneksel -erkeği yücelten ve kadını güçsüzleştirenkalıpyargıları destekleyecek nitelikte olduğu görülmektedir (Turner-Bowker 1996, Tepper ve Cassidy 1999). Çocukların cinsiyet şemalarının oluşumunda medya aracılığıyla tanıdıkları figürlerin büyük önem taşıdığı, özellikle öfke gibi güçlü duygularla başa çıkma şekillerini bu figürlerden örnek alabildikleri ve örnek alınan figürlerin, var olan cinsiyet şemalarını 
güçlendirici veya zayıflatıcı etkiye sahip olduğu belirtilmiştir (Bandura ve Bussey 2004, Dill ve Thill 2007). Bu açıdan bakıldığında, çocuklara erişebilmenin önemli yolları arasında yer alan -çocuklara yönelik- yazılı ve görsel basın malzemelerinin, çocukların sağlıklı cinsiyet gelişimi açısından önemli bir araç olduğu söylenebilir. Geleneksel toplumsal cinsiyet rollerinin çocuk tarafindan benimsenip benimsenmemesini önemli ölçüde etkilediği bilinen bu araç, uygun şekilde kullanıldığı takdirde (örn., kadın-erkek eşitliğinin ön plana çıkarılması gibi), var olan cinsiyet şemalarının çocuğun zihninde daha da aktif hale getirilmesi yerine sönebilmesini sağlayabileceği açıkça görülmektedir.

Bunun yanı sıra psikolojik iyi olma halini belirleyen pek çok unsurdan birinin, bireyin cinsiyet kimliğini ve cinsel yönelimini özgürce ifade edebilmesi ve bu konuda kabul görmesi olduğu bilinmektedir (Egan ve Perry 2001). Öyle ki, benimsedikleri cinsiyet kimliği ve cinsel yöneliminin ebeveynleri ve arkadaşları tarafindan kabul gördüğünü hisseden çocukların özsaygıları, kendilik değerleri, yaşam doyumları ve mutluluk düzeylerinin, kabul görmeyenlere kıyasla daha yüksek olduğu belirtilmektedir (Rosenberg ve Jellinek 2002). Buna karşılık, kendi cinsiyetine yönelik "atipik" davranışlar sergilediği düşünülen ve bu sebeple sosyal baskıya maruz kalan çocukların, içe kapanma, kronik üzgünlük hali, hayal kırıklğı ve kaygı gibi ciddi sıkıntılarla karşılaşııları rapor edilmiştir (Yunger ve ark. 2004). Çalışmaların da tutarlı şekilde göstermiş olduğu gibi, özellikle cinsiyet kimliği ile biyolojik/ atanan cinsiyeti arasında toplumun beklentilerine göre "uyumsuzluk" olan çocukların çevreleri tarafindan kabul görmeleri ve desteklenmeleri, cinsel yönelimleri doğrultusunda özgürce yaşayabilmeleri, onların benlik kavramlarını olumlu yönde etkileyecek ve uzun vadeli psikolojik sağlıkları açısından da büyük öneme sahip olacaktır.

Dolayısıyla, dünya üzerinde pek çok toplumun -hala- geleneksel cinsiyet kalıpyargilarını pekiştiren bir yapıya sahip olduğunu düşünecek olursak, bireyden/aileden başlayacak bir değişimin öneminin farkına varabiliriz. Çocukların hayatlarının ilk yıllarından itibaren anne ve babalarını rol model aldıkları bilinmekte (Bussey ve Bandura 1999, Berk 2017), beklenen şekilde de ebeveynlerin cinsiyet rollerine yönelik inanış ve tutumları çocuklarınınkiyle pozitif yönde ilişkili bulunmaktadır (Tenenbaum ve May 2014). Bu bağlamda, geleneksel toplumsal cinsiyet rollerinin dışına çıkılmış eşitlikçi bir aile ortamında büyümek ("kadınsı" veya "erkeksi” kavramlarının olmadığı, iş bölümlerinin ve çeşitli konulardaki yeterliliklerin cinsiyet ayrımı üzerinden tanımlanmadığı vb.); çocukların kariyer hedeflerini özgürce belirleyebilmeleri (ileride yapacakları mesleği cinsiyetlerine göre değil ilgi alanı ve istekleri doğrultusunda seçebilmeleri), olumlu benlik kavramı gelişimi sergilemeleri ve yüksek benlik saygısına sahip olmaları, sosyal ilişkilerindeki doyum/memnuniyet düzeylerinin daha yüksek olması ve bunun gibi daha pek çok alanda bireylerin sağlıklı psikolojik gelişimi ve iyi oluş halleri üzerinde olumlu yönde önemli bir etkiye sahip olmaktadır (Turner ve Gervai 1995, Hoffman 2000, King ve ark. 2020).

Cinsiyet kalıpyargılarından tamamen bağımsız çocuk yetiştirmek, günümüzde oldukça zor gibi görünse de, çocukların kendi iradeleri, ihtiyaçları, ilgi alanları ve istekleri doğrultusunda özgürce hareket edebilmeleri için cinsiyet rollerine uyum göstermesi yönünde maruz kaldıkları ebeveyn, arkadaş ve toplum baskısından kurtulmaları gerektiği ilgili alanyazın 
1şı̆̆ında açıkça görülmektedir.

\section{Ergenlik}

Dünyayı keşfetmeye çalışan, yeni roller, yeni deneyimler edinmek ve bu doğrultuda kendi kimliğini geliştirmek isteyen ergenler, daha küçük yaşlarına göre daha fazla özerk olmak isterler; ancak ergenlerin özerk olma konusundaki çabaları ebeveynleri tarafından her zaman desteklenmez ve bu durum çatışmalara neden olabilir (Laursen ve Collins 2004). Ebeveynler oğlan çocuklarını bağımsız olmaları, kendilerini daha fazla ortaya koymaları konusunda desteklerken, kız çocuklarına daha fazla kısıtlama getirerek, onları daha uyum gösteren bir şekilde sosyalleştirmeyi tercih etmektedir (Öngen 2004, Leaper 2005). Ebeveynlerin ergen çocuklarına ne kadar özerklik sağladıkları kendi cinsiyet rolleri ile ilişkilidir. Daha geleneksel cinsiyet rollerine sahip olan anneler, ergen kız çocuklarına daha az özerklik tanımaktadır (Bumpus ve ark. 2001).

Oğlan çocuklarına gelişim süreçlerinde daha fazla özerklik verilse de oğlan çocukları küçük yaşlardan itibaren kendi cinsiyetlerine uygun davranmaları konusunda kız çocuklarına göre daha fazla baskıyla karşılaşırlar (Bussey ve Bandura 1999). Kendi cinsiyetlerine uygun davranmamanın sonuçları her iki cinsiyet için aynı olmamakta; kadınsı olarak tanımlanan özelliklere sahip oğlan çocukları -erkeksi olarak tanımlanan özelliklere sahip kız çocuklarına kıyasla- daha uyumsuz ve olumsuz olarak değerlendirilmektedir (Martin 1990). Bu baskının olası bir sonucu olarak ergenliğe geldiklerinde her iki cinsiyetin de kendi cinsiyetlerine özgü davranışlarında artış görülürken (Priess ve ark. 2009), zaman içinde kız ergenlerin cinsiyet rolleri konusunda daha esnek oldukları, oğlan ergenlerin cinsiyet rollerinin ise daha geleneksel bir yönelim gösterdiği bulunmuştur (Crouter ve ark. 2007). Bu konuda ebeveynler de belirleyici bir role sahiptir. Ebeveynin eşitlikçi ya da geleneksel cinsiyet rollerine sahip olması, çocuklarının da benzer cinsiyet rollerine sahip olmalarıla olumlu olarak ilişkilidir (Taylor 2005, Ashraf 2015). Ancak bu konuda annenin çocuklar üzerindeki etkisi babaya göre daha güçlüdür (Taylor ve Segrin 2010).

Cinsiyet rolleri konusunda kültürlerarası çalışmalara bakıldığında, 36 farklı ülkede ergenlerle yapılan bir çalışmada, araştırma verilerinin toplandığı tüm ülkelerde kız ergenlerin, oğlan ergenlere göre cinsiyet açısından daha eşitlikçi tutumlara sahip oldukları bulunmuştur (Dotti-Sani ve Quaranta 2017). Cinsiyet rollerine yönelik tutumlarda sosyoekonomik koşulların ve kültürün de belirleyici olması olasıdır. Gibbons ve arkadaşları (1991) 46 farklı kültürden ergenlerin, toplumsal cinsiyet rolleri ile ilgili tutumlarını araştırdıkları çalışmada, refah düzeyi düşük ve toplulukçu kültürlerde yetişen ergenlerin, refah düzeyi yüksek ve bireyci kültürlerde yetişen ergenlere kıyasla, daha geleneksel tutumlara sahip olduklarını bulmuşlardır. Cinsiyet farklılı̆̆ına bakıldığında ise diğer araştırma bulguları ile tutarlı olarak oğlan ergenlerin, kız ergenlere kıyasla daha geleneksel tutumlara sahip oldukları görülmüştür.

Kültürlerarası yürütülen bir diğer çalışmada benlik saygısı konusundaki cinsiyet farklılıklarının, tüm gelişim dönemleri arasında ergenlik döneminde zirveye ulaştığı rapor edilmiştir (Kling ve ark. 1999). Kız ergenlerin kendi fiziksel görünüşlerine yönelik algılarının 
ve matematik becerileri ile zeka düzeylerine yönelik benlik değerlendirmelerinin, oğlan ergenlere kıyasla daha olumsuz olduğu belirtilmiştir (Watkins ve ark. 1991). Kız ergenler kendilerinin genellikle okuma alanında ve kişiler arası ilişkilerde iyi olduklarını düşünürken, oğlan ergenlerin ise matematiğin yanı sıra fiziksel beceriler ve görünüş konusunda benlik saygıları yüksektir (Kling ve ark. 1999).

Kız ergenlerin olumsuz beden imgesine sahip olmalarında medyanın önemli bir etkiye sahip olduğu görülmektedir. Birçok kız ergen, kendi ve diğer insanların bedenlerini karşılaştırırken, medya görselleri, onlara yanlı bir içerik sunarak kendilerine yönelik olumsuz bir algıya neden olmaktadır (Wiseman ve ark. 2005). Örneğin yapılan deneysel bir çalışmada, fiziksel olarak idealleştirilmiş bir görünüşe sahip (kadın karakterlerin oldukça ince, erkek karakterlerin kaslı olduğu) kişilerin oynadığı televizyon reklamları kız ve oğlan ergenlere izletilmiş, ardından beden memnuniyetleri değerlendirilmiştir. Sonuçlar oğlan ergenlere göre kız ergenlerin idealleştirilmiş medya içeriklerine maruz kalmalarının görünüşlerine ilişkin daha fazla karşılaştırma yapmalarına neden olarak, beden memnuniyetlerini olumsuz etkilediğini göstermiştir (Hargreaves ve Tiggemann 2004). Kı ergenlerin oğlan ergenlere göre sosyal medyada daha fazla zaman geçirdiğine ilişkin bulgular onların bu konuda daha fazla risk altında olabileceğine işaret etmektedir (Yüksel-Şahin ve Öztoprak 2019). Nitekim, Tiggemann ve Slater (2013) internette daha fazla zaman geçiren kız ergenlerin zayıf olmak için daha fazla çaba gösterdiklerini rapor etmiştir. Aslında oğlan ergenler de fiziksel görünüşe ilişkin kaygıdan bağımsız gözükmemekte, özellikle ergenliğin sonuna doğru kaslı görünüşe sahip olma konusunda çabalarında artı̧̧ görülmektedir (McCabe ve Ricciardelli 2001).

Fiziksel görünüşün yanı sıra ergenlerin becerilerine ilişkin benlik değerlendirmeleri konusundaki farklılığın ise sosyalleşme süreçlerindeki farklıçevresel etkilerden kaynaklanması olasıdır. Diğer bir deyişle, ebeveynler, çocuklarıyla yaptıkları sohbetlerde, çocuklarının cinsiyetine bağlı olarakaynı konuda farklı temalara odaklanan bir iletişim kurarakçocuklarının cinsiyet gelişimlerini etkilemektedir. Aile içinde gözlemlenen cinsiyet rollerine yönelik tutum ve davranışların, ergen çocukların kariyer planlamaları üzerine etkisinin araştırıldı̆̆ bir çalışmada, annelerin kız çocukları ve oğlan çocukları ile kariyer planlaması ile ilgili yaptıkları sohbetler incelenmiştir. Annelerin kız çocuklarıyla farklı seçeneklere açık olma ve iş ortamında ilişkisel bağlamda etkili davranabilme üzerine sohbet ettikleri gözlemlenirken; oğlan çocuklarıyla olan sohbetlerinin akademik başarı ve işte yükselme üzerine yoğunlaştığ bulunmuştur (Domene ve ark. 2007). Dolayısıyla, ergenlerin ailelerinden algıladıkları eşitlikçi veya geleneksel cinsiyet rollerine ilişkin tutumlar, kendilerinin yetişkinlik dönemlerine yönelik hedef, meslek seçimi ve kariyer planlamalarını etkileyebilmektedir (Ruble ve ark. 2006). Ergenler, kendi becerileri konusunda cinsiyet kalıpyargılarına ebeveylerinin yanı sıra öğretmenleri aracılığıyla da maruz kalmaktadır (Shapiro ve Williams, 2012). Örneğin kız ögrencilerin matematik becerileri konusunda oğlanlara göre daha yetersiz olduklarına ilişkin cinsiyet kalıpyargılarına sahip olan öğretmenlerin öğrencilerinin de benzer kalıpyargılara sahip oldukları ve zaman içinde gerçekten kız öğrencilerin matematik performanslarının daha kötü olduğu rapor edilmiştir (Beilock ve ark. 2010). 
Ebeveynlerin kız ve erkek ergenlere yönelik tutum ve davranışlarında bir başka farklılık da yakınlık derecesidir. Kız ergenlerin, erkek ergenlere göre ebeveynleri ile daha yakın olmaları beklenmektedir (Leaper 2005) ve kız ergenler, erkek ergenlere göre annelerinden daha fazla sevgi gördüklerini düşünmektedir (Öngen 2004). Bunun bir sonucu olarak ülkemizde yapilan bir çalı̧̧mada kız ergenlerin, erkek ergenlere göre anne ve babalarına bağlanma puanlarının daha yüksek olduğu bulunmuştur (Doğan 2016). Küçük yaşlardan itibaren duygularını ifade etme ve yakınlık gösterme konusunda daha fazla sosyalleştirilen kız çocuklarının ergenlik dönemine geldiklerinde de sadece aileleri ile değil, arkadaşları ile de daha yakın ilişkilere sahip oldukları görülmektedir. Kız ergenlerin, erkek ergenlere göre arkadaş ilişkileri daha yakın ve derindir, arkadaşlarına daha fazla bağlanırlar ve kendi iç dünyalarını arkadaşlarına daha fazla açarlar (Swenson ve Rose 2009, Gorrese ve Ruggieri 2012).

Arkadaşlarla daha fazla yakınlık kurma gibi yeni konularla başa çıkmaya çalışan ergenler (Kroger 2006), bir taraftan da kimlik gelişimlerinin bir parçası olarak cinsiyet gelişimlerini sürdürürler. Ergenlik döneminde bireylerin kendi cinsiyetlerine özgü davranışlarında ve tutumlarında bir artış görülmektedir. Bu artışın nedenleri, ergenlerin bu dönemde cinsiyet rollerine uygun davranmaları konusunda hem sosyal çevre hem de çeşitli medya kaynakları aracılığıyla daha fazla baskı hissetmeleri ve arkadaşları arasında kabul görmeme veya yargılanma endişesiyle de uyum sağlama eğilimi göstermeleridir (Ridgeway ve Bourg 2004, Priess ve ark. 2009). Çocukluk döneminde daha erkeksi olarak tanımlanan özelliklere sahip olan kız çocuklarının bile bu dönemde kadınsı olarak tanımlanan yönlerinde artış olduğu görülmektedir (Clarke-Stewart ve Parke 2014). Erkeksi olarak tanımlanan özelliklere sahip olan kızların ergenlik döneminde kadınsı özelliklerinde artı̧̧ görülse de yetişkinlik döneminde diğer kadınlara göre daha erkeksi olarak tanımlanan özelliklere sahip olmaya devam etmektedirler (Volkom 2003).

Ergenlik dönemi arkadaşlık ilişkileriyle beraber romantik ilişkilerin de ön plana çıktığı bir gelişimsel süreçtir ve ergenler cinsiyet gelişimlerinin bir parçası olarak cinsiyet kimliklerini ve cinsel yönelimlerini keşfetme sürecindedir (Bouchey ve Furman 2006). Bazı ergenler cinsel yönelimlerini heteroseksüel olarak tanımlarken, bazıları da kendilerini LGBTQ + (lezbiyen, gey, biseksüel, transseksüel, kuir -queer- vb.) olarak tanımlamaktadır (Levitt 2019). Genellikle LGBTQ+ bireylerin, ergenlik döneminden önce cinsiyet kimliklerine ve cinsel yönelimlerine ilişkin farkındalıkları artarken, cinsiyet kimliklerini ve cinsel yönelimlerini tanımlamaları ergenlik döneminin ortalarına doğru gerçekleşmektedir (D’Augelli ve ark. 1998). LGBTQ + ergenler gelişim süreçleri boyunca hem bireysel hem de çevresel stres kaynaklarıyla başa çıkmaya çalışmaktadır. Bir taraftan biyolojik/atanan cinsiyetleri ile cinsel yönelimleri arasında toplumun heteronormatif beklentileri dolayısıyla bir çatışma hissedip hemcins arkadaş grubundan "farklı" olmanın stresini yaşarken, diğer taraftan aile ve sosyal çevre baskısı ve dışlanma ile karşılaşabilmektedirler (Morrow 2018, Rafferty 2018). Karşılaştıkları bu toplumsal baskı ve dışlanmanın bir sonucu olarak bu ergenler daha fazla oranda depresyon yaşamaktadır ve yaşam doyumları daha düşüktür. Aile desteğine sahip olmaları psikolojik sağlıklarında koruyucu rol oynamaktadır (Simons ve ark. 2013), ancak genellikle bu desteğe sahip olmadıkları görülmektedir (Morrow 2018). LGBTQ+ ergenlerin 
psikolojik sağlık açısından risk altında olmaları, konuya dair bilgi düzeyinin toplum genelinde düşük olması durumundan kaynaklanabilmektedir. Bu bağlamda, sağl1k personelleri ve bu alanda çalışan uzmanların bu konuda hem ergenleri hem de aileleri bilgilendirme ve yol gösterme konusundaki çabaları oldukça önemli olacaktır. Bu farkındalıkla son yıllarda "cinsiyet olumlayan bakım" yaklaşımı üzerinde durulmaktadır. Bu yaklaşım, geleneksel toplumsal cinsiyet normlarıyla paralel olmayan cinsel kimlik gelişiminin psikolojik bir bozukluk olmadığı ve bireyler arası farklılığın son derece normal olduğu fikrini temel alarak, LGBTQ+ birey ve ailelerini bilgilendirme ve desteklemeye yönelik hizmetlerin sunulmasını içermektedir. Bu süreçte ergenin benlik gelişimi zarar görmeden, cinsiyet kimliğini ve cinsel yönelimini keşfetmesi ve geliştirmesi ile bu süreçte ihtiyaç duyduğu hizmetlere ulaşması hedeflenmektedir (Rafferty 2018).

\section{Yetişkinlik}

Genç yetişkinlik dönemi hem kadınlar hem de erkekler için çevrelerindeki bireylerle yakınlık ihtiyacının arttığı bir dönemdir (Burleson 2003). Bebeklik döneminden başlayarak çevre tarafından şekillendirilen sosyal ilişki kurma biçimi, birey yetişkin olduğunda ilişkilerini nasıl kuracağını belirlemektedir. Bu kapsamda, duygularını ifade etme, yakınlık gösterme gibi konularda farklı sosyalleştirme uygulamalarına maruz kalan kız ve oğlan çocukları, yetişkin olduklarında da ilişki kurma biçimleri açısından farklılık göstermektedir. Kadınlar yaşadıkları sorunları diğer insanlarla paylaşma, kendilerini onlara açma gibi sosyalleşme yöntemlerini daha fazla tercih ederken, erkekler tarafından bu yöntemlerin daha az tercih edildiği görülmektedir (Consedine ve ark. 2007, Sultan ve Chaudry 2008). Sosyal medya üzerinden kurulan arkadaşlıklarda da kendi özel duygu ve düşüncelerini anlatmada benzer cinsiyet farklılığı görülmektedir (Sheldon 2013).

Erkekler çok sayıda arkadaşa sahip olmalarına karşın, kendi aralarındaki duygusal yakınlığın derecesi, kadınların arkadaş ilişkinlerindeki kadar fazla değildir (Marshall 2010). Bu nedenle olumsuz durumlarda destek almak için erkekler de kadın arkadaşlarını daha fazla tercih etmektedir (Buhrke ve Fuqua 1987). Kadınların sosyal ilişkilerinde kurdukları yakınlığın erkeklere göre daha fazla olması, destek aranılan olumsuz durumlarda daha fazla tercih edilmelerinde rol oynamaktadır. Örneğin kadınlar ilişkilerinde daha fazla destekleyicidir ve daha fazla yardım davranışı göstermektedir (Weger ve Emmett 2009). Benzer şekilde kadınlar arkadaşları ile bir araya geldiklerinde duyguları ve problemleri hakkında sohbet etmeyi tercih ederken, erkekler ise sohbet etmek yerine spor gibi çeşitli aktivitelere katılma eğilimindedir (Caldwell ve Peplau 1982).

Yetişkinlik döneminde iş yaşamı da toplumsal cinsiyet rollerinin etkisinin hissedildiği, incelenmesi gereken alanlardan bir diğeridir. 1960'lı yıllardan itibaren kadınların birçok ülkedeki sosyal pozisyonları radikal bir biçimde değişmeye başlamıştır. Artan eğitim seviyelerinin yanı sıra zaman içerisinde değişen sosyal ve kültürel faktörlerin de etkisiyle kadınlar giderek artan oranlarda çalışma hayatına dahil olmuş; yemek yapma, çocuk bakma, işten gelen eşine hizmet etme gibi beklentilerin yavaş yavaş dışına çıkarak, anne 
rollerinin yanı sıra iş insanı rolünü de benimsemeye başlamıştır (, Peake ve Harris 2002, Hofnung 2004, Amuedo-Dorantes ve Kimmel 2005). Bu değişim günümüz kadınlarının ve erkeklerinin kendi üst nesillerine göre daha az geleneksel cinsiyet rollerine sahip olmalarını sağlamıştır (Chesley 2011). Kadınlar iş yaşamında daha güçlü bir hale gelmiştir ve farklı birçok iş sektöründe üst pozisyonlarda yer alabilmektedir (Arnett 2016).

Geçmiş yıllardan günümüze cinsiyet eşitliği konusunda önemli kazanımlar elde edilmekle birlikte (Carlson ve Knoester 2011), halen çok sayıda ülkede cinsiyet eşitsizliği söz konusudur. Dünyada 189 ülkenin \%39'unda kadınlar düşük-orta derecede cinsiyet eşitliğine sahiptir (UNDP 2019). Geleneksel değerler, kadınların toplumsal pozisyonlarının tanımlanmasında halen oldukça güçlüdür. Kadınların ev dışında çalışma oranları artmış, ancak ev işleri ve çocuk bakımı gibi aile sorumluluklarında önemli bir değişiklik olmamıştır (Paçacıŏlu 2018). Kadınların geleneksel cinsiyet rolleri temelinde sorumluluklarını sürdürmelerine ilişkin beklenti devam etmektedir (Koivunen ve ark. 2009). Türk kültüründe de kadınların kendilerini tanımlamada en önemli gördükleri kimlik boyutu eğitim ve meslek yerine hala ailedir (Gezici 2002); ve anne olmanın, toplumda kadına statü ve güç kazandırdığı kabul edilmektedir (Y1lmaz 2004).

Kadınların temel görevinin annelik olarak görülmesinin bir sonucu olarak kadınların iş yaşamına katılımları desteklenmemektedir (Cinamon ve Rich 2002, Fortin 2005). Dünyada pek çok ülkede kadınların işgücüne katılım oranları erkeklerin gerisindeyken, Türkiye'de de bu oranlar gelişmiş ülkelerin oldukça gerisindedir (UNDP 2019). Türkiye İstatistik Kurumu (2018) verilerine göre Türkiye'de erkeklerin $\% 71,5$ 'i iş gücüne katılırken, kadınların yalnızca \%33,3’ü kat1lmaktadır. Toplumsal düzeyde geleneksel rollerini sürdürmeleri beklenen, buna karşın bir kariyere sahip olmayı isteyen kadınlar önemli zorluklarla karşılaşmaktadır. Erkekler gibi eşit sürelerde iş gücüne katılmalarına karşın değişmeyen ev sorumlulukları sebebiyle sık sık aile-iş çatışması yaşamakta (Milkie ve Peltola 1999), bu durum kadınların fiziksel ve psikolojik sağlıklarını olumsuz etkilemektedir (Poms ve ark. 2016). Ebeveynlik, erkeklerin ev işlerine dair sorumluluklarında çok az değişikliğe neden olurken, kadınların yükünü önemli miktarda artırmaktadır (Cowan ve ark. 1985, Sanchez ve Thomson 1997). Özellikle tam zamanlı çalışan, evli ve küçük çocuğu olan kadınlar, ev ve iş sorumluluklarını dengeleme konusunda erkeklere göre daha fazla sorun yaşamaktadır (Milkie ve Peltola 1999). Örneğin hastalandığı için çocuğun okula gidememesi durumunda kadınlar, erkeklere kıyasla çocuklarına bakmak için işyerlerinden daha fazla izin almaktadır (Lindsey 2015). Aile-iş çatışmasının yanı sıra hem evlilik hem de ebeveynlik sorumlulukları kadınların boş zamanlarını da önemli ölçüde sınırlandırmaktadır. Erkeklerin ise artan çocuk sayısı boş zamanlarını azaltırken, evliliğin boş zamanları üzerinde olumsuz bir etkisinin olmadığı rapor edilmiştir (Mattingly ve Bianchi 2003).

Kadınlar ve erkekler arasındaki aile ve ev işlerine dair bu dengesiz iş yükünün sürmesinde öncelikle yukarıda anıldığı gibi geleneksel cinsiyet rolleri temelinde sosyalleştirme süreçlerinin rolü büyüktür. Çocukluk dönemlerinde çalışan kadınla daha fazla karşılaşan erkekler, ilerleyen yaşlarda diğer erkeklere göre daha fazla ev işi yapmakta (Koivunen ve ark. 2009) ve aile üyeleri ile ilgilenmek için daha fazla zaman ayırmaktadır (McGinn ve 
ark. 2015). Hem kadınların hem de erkeklerin ebeveyn olduktan sonra geleneksel cinsiyet rollerinde artı̧̧ olmakla birlikte, bu artı̧̧ kadınlarda daha fazla görülmektedir (Katz-Wise ve ark. 2010). Bu kapsamda geleneksel rollerin dışına çıkan, eşit sorumluluklara sahip olmayı savunan, eşitlikçi cinsiyet rolüne sahip olan kadınlar ev sorumluluklarındaki dengesizliği daha az yaşamaktadır (Weisner ve ark. 1994).

Bu bireysel ve ailevi faktörlerin ötesinde, yaşamı çevreleyen medya ve ülke politikalarının da cinsiyet rollerinin içeriği ve benimsenmesinde güçlü bir etkiye sahip olduğunu söylemek mümkündür. Medya araçları, geleneksel cinsiyet rollerine ilişkin algıyı desteklemekte, örneğin reklamlarda kadınlar daha çok ev işleriyle meşgul bir şekilde gösterilmektedir (Lindsey 2015). Ülke politikaları düzeyinde bakıldığında ise dünyada birçok ülkede hükümetlerin görüşü de aile görevlerinin kadın tarafından yerine getirilmesi yönündedir. İskandinav ülkeleri dışında dünyadaki çok sayıda ülkede doğum izni, yaşıı bakım izni gibi konularda kadınlara göre erkekler daha sınırlı haklara sahiptir (Datta-Gupta ve ark. 2008, Maume 2016).

Kadınlar geleneksel rolleri sürdürmeleri konusunda baskıyla karşılaşırken aslında erkeklerin yaşamında da sosyal baskılar bulunmaktadır. Erkeklerin birçok toplumda birincil rolleri evin geçimini sağlayan temel kişi olmaktır. Bu durum erkek üzerinde önemli bir strese neden olmakta, herhangi bir nedenle işsiz kalan bir erkeğin psikolojik sağllğı, işsiz kalan bir kadına göre daha olumsuz olarak etkilenmektedir (Artazcoz ve ark. 2004). Ancak ne kadar duygusal olarak zorlansalar da toplum tarafindan erkeksi olarak tanımlanan cinsiyet rolleri doğrultusunda sert, baskın, bağımsız ve güçlü görünmeleri, duygularını belli etmemeleri beklenmektedir (Clarke-Stewart ve Parke 2014, Arnett 2016). Belki de bunun bir sonucu olarak yapılan çalı̧malarda erkeksi özelliklerin yanı sıra kadınsı özelliklere de sahip olan erkeklerin psikolojik sağlığının daha iyi olduğu rapor edilirken (Lefkowitz ve Zeldow 2006), cinsiyet kalıpyargılarına dayalı davranışlara sahip olan erkeklerde ise daha yüksek oranda depresyon görüldüğü belirtilmiştir (Gupta ve ark. 2013). Cinsiyet rolleri ve psikolojik sağllk arasındaki ilişkide eğitim düzeyinin de önemli bir değişken olduğu görülmektedir. Yapılan bir çalışmada kadınsı özelliklere sahip olan erkeklerin daha iyi psikolojik sağllğa sahip olmalarının üniversite mezunu olmaları halinde daha olası olduğu bulunmuştur. Daha düşük eğitim seviyesine sahip olan erkeklerde ise erkeksi özelliklere sahip olmanın daha iyi psikolojik sağlıkla ilişkili olduğu rapor edilmiştir (Gibson ve ark. 2016).

Aslında, kadınların sosyal yaşamlarındaki değişiklik kadar belirgin olmamakla birlikte "erkeklik rolü” tanımları da değişim geçirmeye başlamıştır. "Evdeki disiplini sağlayan, eve ekmek getiren, cinsiyet-rol modeli” gibi ön plana çıkan babalık rolleri günümüzde "çocuğu ile daha çok ilgilenen, ona bakım veren" olarak değişmeye başlamıştır (Lamb 2000, Bianchi ve Milkie 2010). Günümüz babaları çocuklarının yaşamlarındaki rollerini daha fazla önemsemeye başlamıştır ve bu durum onların çocuklarına bakım verme sürelerini artırmıştır (Chesley 2011).

Bu değişimin bir uzantısı olarak birçok ülke "gelenek dışı" baba modeliyle tanışmaya başlamıştır. Değişen sosyal ve ekonomik koşullar sebebiyle giderek artan sayıda baba işe gitmek yerine evde kalarak çocuklarının bakımını üstlenmektedir. Bu durum genellikle 
bebeğin bakımını üstelenecek bir kişinin bulunamaması ve annenin, babaya göre daha yüksek eğitim seviyesine sahip olması, dolayısıyla da daha yüksek gelirli bir işte çalışması durumunda ortaya çıkmaktadır (Grey 2015, Kramer ve ark. 2015). Tam zamanlı evde kalan babalar, yüksek yaşam doyumuna ve düşük stres düzeyine sahipken (Rochlen ve ark. 2008) hem kendi hem eşlerinin pozisyonundan memnun olma eğilimindedir ve bu iş bölümünün ailelerinin esenliği için daha iyi olduğuna inanmaktadır (Masterson ve Hoobler 2015). Ancak bu babalar toplumda önemli bir baskıyla karşılaşmaktadır ve diğer ebeveynler bu kişiler hakkında daha olumsuz tutuma sahiptir (Brescoll ve Uhlmann 2005, Grey 2015). Tam zamanlı evde kalan kişinin baba olduğu bazı ailelerde ise anne işten döndükten sonra roller yeniden değişerek geleneksel rol paylaşımına dönülmektedir. Bu anneler akşamları ve haftasonları aile sorumluluklarını sürdürmektedir. Babalar bunun eşlerinin çocuklarının bakımı ve ev işleri konusunda yüksek standartlara sahip olmaları nedeniyle kendi yaptıklarını beğenmemelerinden kaynaklandığını belirtirken, aynı zamanda anneler çocuklarıyla yeterince vakit geçiremedikleri için suçluluk duygusu ile başa çıkmak amacıyla bu görevleri üstlenmektedir (Latshaw ve Hale 2015). Babaların evde kalmasının nedeni çocuklarının bakımını üstlenmekken, önemli sayıda baba da iş bulamadığı için evde çocuklarıyla kalmaktadır. Çocuklarının bakımını üstlenmek için tam zamanlı evde kalmayı tercih eden babaların sayısının ise giderek arttı̆̆ı rapor edilmiştir (Kramer ve ark. 2015, Kramer ve Kramer 2016).

Bahsedilen bu sosyal değişim aslında günümüz erkeklerinin kendi ebeveynlerinden daha az geleneksel olduğunu doğrulamaktadır (Chesley 2011). Halen bu değişim konusunda toplumsal direnç birçok ülkede güçlü olsa da, eşitlikçi yaşam anlayışı erkeklere evlilikleri açısından önemli avantajlar sağlamaktadır. Eşitlikçi cinsiyet tutumlarına sahip olan erkeklerin boşanmaları daha az olasıdır (Kaufman 2000). Aynı zamanda bu erkekler orta ve ileri yetişkinlikte evliliklerini daha olumlu olarak değerlendirmektedir (Kaufman ve Taniguchi 2006). Öte yandan bazı araştırmacılar eşitlikçi cinsiyet tutumuna sahip olan erkeklerin her zaman yüksek evlilik doyumuna sahip olmadığını, eşlerin cinsiyet ideolojilerinin benzer olması durumunda erkeklerin evlilik doyumunun yüksek olduğunu belirtmişlerdir (Lye ve Biblarz 1993, Minnotte ve ark. 2010). Eşitlikçi erkekler çocuk yetiştirmenin her iki ebeveynin de görevi olduğunu düşündükleri için çocuk bakımında eşleri ile ortak sorumluluk almaktadır (Kaufman 2000). Erkeklerin geleneksel rollerin dişına çıkarak çocuklarının bakımına katılmaları eşlerinin hem daha yüksek bir evlilik doyumuna sahip olmasını (Kalmijn 1999) hem de daha etkili bir ebeveynlik göstermesini desteklemektedir (Allen ve Daly 2007). Eşitlikçi cinsiyet rollerine sahip olan kadınlar ise bu tutumları çevre tarafından her zaman desteklenmediği için erkekler kadar avantajlı gözükmemektedir. Bu durumda eşitlikçi tutuma sahip olma kadınlarda düşük evlilik doyumu ile ilişkili olabilmekte (Minnotte ve ark. 2010) ve ev işlerindeki dengesiz görev dağılımı evlilik doyumlarını olumsuz etkilemektedir (Oshio ve ark. 2005).

\section{Yaşlılık}

Küçük yaşlardan itibaren duygularını belli etmemek üzere sosyalleştirilen oğlan çocukları 
her yaş döneminde bunun zorluklarını yaşamakla birlikte, ilgili araştırma bulguları, yaşlılık döneminde bu eğilimlerin sağlık açısından daha fazla olumsuz sonuçları olduğuna işaret etmektedir. Duyguların paylaşılması stresle başa çıkmada önemli bir mekanizmadır. Ancak bu yöntemin çocukluk yıllarından itibaren zayıllık ve yetersizlik olarak etiketlenmiş olması, erkeklerin ileri yaşlarda dahi bu yöntemi kullanmalarını engellemektedir. Yapılan çalışmalar kadınların olumsuz bir durumla karşılaştıklarında destek almayı ve duygularını paylaşmayı tercih ederken, erkeklerde bunun daha sınırlı olduğunu göstermiştir (Melendez ve ark. 2012). İleri yaştaki kadınlar, ileri yaştaki erkeklere göre daha geniş sosyal ilişki ağına sahip olmaları nedeniyle daha farklı ve daha fazla kaynaktan destek alabilmektedir. Erkekler ise genellikle eşlerinden sosyal destek sağlamaktadır (Antonucci ve Akiyama 1987). Sosyal ilişkilerde görülen bu farklılık, ileri yaşa özgü olmaktan ziyade, yukarıda da anıldığı gibi genç yaşlardan itibaren kadınların, erkeklere göre daha ilişki yönelimli bir tarza ve daha fazla sosyal çevreye sahip olmaları ile ilişkilidir ve bu durum ileri yaşlarda da sürmektedir (Vandervoort 2000). Yaşı kadınlar, yaşlı erkeklere göre daha fazla sosyal desteğe sahiptir. Sosyal ilişki ağının genişletilmesi ise yaşlılık döneminde özellikle erkekler için daha yararlı gözükmektedir. Erkeklerin sosyal destek düzeyi arttıkça sağlıklarının da daha iyi olduğu bulunmuştur (Okamoto ve Tanaka 2004).

Ancak sosyal destek almayı daha az tercih etmenin yanı sıra birçok erkek yaşadığı stresle başa çıkma yöntemi olarak alkole -kadınlara kıyasla- daha yüksek oranda başvurmaktadır (WHO 2002). Bu durum ise hem psikolojik hem fiziksel sağllğ́1 olumsuz yönde etkilemektedir. Dünyada Türkiye de dahil birçok ülkede nüfus istatistikleri incelendiğinde, kadınların erkeklere göre daha uzun yaşadığı rapor edilmektedir (He ve ark. 2016, TÜİK 2020). Uzun yaşam açısından kadınlar ekstra X kromozomuna, daha yüksek östrojen hormonuna sahip olma gibi fiziksel açıdan çeşitli avantajlara sahip olmakla birlikte, çok sayıda araştırmacı duyguları paylaşmanın ve daha fazla sosyal desteğe sahip olmanın kadınların daha uzun yaşamasında önemli rol oynadığını düşünmektedir (WHO 2002, Austad 2006, Ostan ve ark. 2016).

Kadınlar sadece başkalarından destek almamakta, başka insanlar olumsuz bir durum yaşadığında da daha fazla destek vermektedir. Örneğin evli erkeklere şizofreni tanısı konulduğunda eşleri hem bakım hem ekonomik destek sağlarken, kadınlara aynı tanı konulduğunda eşleri tarafından terk edilmeleri ya da boşanmaları daha olasıdır (WHO 2002). Aslında ileri yaşta bireylerin genellikle desteğe ihtiyaç duydukları düşünülmekle birlikte destek olmak da onların sağlı̆ğna iyi gelmektedir (Brown ve ark. 2003). Örneğin eşlerine ve sosyal çevrelerine destek sağlamanın sadece kadınlarda değil erkeklerde de daha az depresyonla ilişkili olduğu bulunmuştur (Tsuboi ve ark. 2016). Ancak yaşlı kadınlar için bakım vermenin yararlı olduğunu söylemek her zaman mümkün olmamaktadır. Yaşlı kadınlar hem torunlarının hem de kendilerinden daha yaşlı olan ebeveynlerinin bakımını üstlenmektedir. Birçok toplumda bakım verme görevi yaşlı kadınlardan beklenmekte, bu durum onların sağlıklarını olumsuz etkileyebilmektedir (Zahidi 2012).

İlerleyen yaşla birlikte hem kadınların hem erkeklerin cinsiyet özelliklerinde farklılıklar meydana gelmektedir. Kadınların kadınsı olarak tanımlanan özelliklerinde, erkeklerin 
de erkeksi olarak tanımlanan özelliklerinde azalma görülmekte, her iki cinsiyet de diğer cinsiyete ait olduğu düşünülen özellikleri de göstermeye başlayarak daha androjen hale gelmektedir (Livson 1983). İleri yaştaki yetişkinler kadınsı, erkeksi ve androjen özellikler açısından karşılaştırıldığında hem kadınlarda hem de erkeklerde androjen özelliklerin daha fazla görüldüğü rapor edilmiştir. Aynı zamanda ileri yetişkinlikte yüksek düzeyde androjen özellikler daha düşük oranda depresyonla ve daha iyi fiziksel sağlıkla ilişkiliyken (Vafaei ve ark. 2014, 2016), kadınsı özelliklerin daha kötü fiziksel sağlıkla ilişkili olduğu rapor edilmiştir (Willerth ve ark. 2020). Benzer şekilde, yapılan bir diğer çalışmada da orta ve ileri yetişkinlik dönemindeki kadınlarda erkeksi özellikler daha yüksek benlik saygısı ve yeterlik duygusu ile ilişkiliyken, kadınsı özellikler daha yüksek stres düzeyiyle ilişkili bulunmuştur (Frank ve ark. 1985).

İleri yaşlarda, erkeklerin de kadınlar gibi toplumsal cinsiyet rollerinde dönüşüm yaşayarak erkeksi olarak tanımlanan özelliklerinde azalma olması, bu baskın özellikleri ileri yaşlarda sürdürmelerinin artık çok da uyumsal bir yöntem olmamasından kaynaklanmaktadır. Erkeklerin toplum içindeki güçlü, baskın pozisyonlarının daha esnek hale gelmesi ve azalan fiziksel güçleri sebebiyle eskisi kadar bu özelliklerini sürdüremedikleri görülmektedir (Livson 1983, Arnett 2016). Cinsiyet rollerindeki yaşla ortaya çıkan bu farklılığın azalan hormon değerlerinden de kaynaklandığı düşünülmektedir. Erkekler de kadınlar gibi yaşla birlikte hormonal değişim geçirmekte, orta yetişkinlik döneminden itibaren testosteron düzeyleri azalmaktadır (Feldman ve ark. 2002).

Geleneksel, kadınsı olarak tanımlanan özelliklere sahip olma kadınların genç yaşlarda toplumsal açıdan kabul görmeleri gibi çeşitli avantajlar sağlarken (Brescoll ve Uhlmann 2005), ilerleyen yaşlarda yüksek oranda kadınsı olarak tanımlanan özelliklere sahip olmanın kadınlar için dezavantajlı olabildiği ve bu nedenle çeşitli uyum problemleri ile karşılaşabildikleri rapor edilmiştir. Kadınsı olarak tanımlanan özelliklere daha fazla sahip olan kadınlar, daha bağımsız, özerk özelliklere sahip olan kadınlara göre eş kaybıyla başa çıkmakta daha fazla zorlanmakta, diğer aile üyelerinin desteğine ve yakınlığına daha çok ihtiyaç duymaktadır (Livson 1983). Bazı durumlarda ise orta yaşlarda daha bağımsız ve özerk özelliklere sahip olan kadınların yaşları ilerlediğinde daha bağımlı olma gibi kadınsı olarak tanımlanan özelliklerinde artı̧̧ olabilmektedir. Güçlü, bağımsız, özerk bir kişiliğin diğerlerinin desteğini alması daha az olası olacağı için, ilerleyen yaşta diğerlerinin yardımına daha çok ihtiyaç duymaları nedeniyle daha kadınsı olarak nitelendirilen özellikler gösterme olasılıkları artmaktadır (Clarke-Stewart ve Parke 2014). Bu durumun ekonomik koşullardan kaynaklanması da olasıdır. Kadınlar eğitim ve çalışma koşullarında yaşam boyu erkeklerle aynı fırsatlara sahip olamamaları sebebiyle, ileri yaşlarda onlara göre daha düşük ekonomik koşullara ve yaşam standartlarına sahiptir (Beard ve ark. 2012).

Kadınların cinsiyet rollerinde ileri yaşlarda görülen dönüşüm, özellikle geleneksel toplumlardaki kadınlar için avantaj sağlamaktadır. Bu toplumlarda kadınlar küçük yaşlardan itibaren ikincil pozisyona sahiptir. Genç kadınlar; eşinin ailesindeki kadın ve erkek fark etmeksizin kendisinden büyük olan kişilere hizmet etme, onların taleplerine boyun eğme, onlar yemeklerini bitirmeden yemek yemeye başlayamama gibi bazı katı 
uygulamalara tabidir. İleri yaşlarda ise sosyal konumları oldukça güçlü hale gelmektedir (Özonur-Çöloğlu 2009, Arnett 2016, ). Bu durum aslında üstü kapalı bir şekilde yine kadını güçsüzleştiren ve geleneksel toplumsal cinsiyet kalıpyargılarını besleyen ataerkil bir sistemden kaynaklanmaktadır. Kadının yaşı arttıkça statüsü güçleniyor gibi görünürken, gerçekte kadının statüsü oğlan annesi olması ya da eşinin ölmesi gibi durumlar aracılığıyla, yine çoğunlukla erkek üzerinden belirlenmektedir. Örneğin aile ilişkilerine bakıldığında erkek eşin annesinin, kadın eşüzerinde güçlü bir otoriteye sahip olduğu gözlemlenmektedir (Arnett 2016, Kuru 2016). Bu kapsamda oğlan çocuk anneleri, kız çocuk annelerine göre ileri yaşlarda daha fazla toplumsal güce sahiptir. İleri yaştaki anne, ailede kutsal, sözü dinlenmesi gereken kişi olarak görülmektedir ve baba öldüğünde aileyi yöneten kişi pozisyonuna geçmektedir (Y1lmaz 2004). Bu geleneğe göre yetişkinlik döneminin başında "taze gelin" olarak tanımlanan kadının sosyal statüsü oldukça düşükken, ailedeki diğer erkek çocukların evlenmesi ile "kıdemli gelin” statüsüne geçmekte, kendi çocuğu da evlendiğinde en üst pozisyon olan "kayınvalide/kaynana" statüsüne yetişkinlik döneminin sonunda erişebilmektedir (Özonur-Çöloğlu 2009). Kadının tüm yaştaki erkeklerden ve yaşlı kadınlardan daha alt statüde olduğu bu gelenek, Asyalı toplumlarda daha yaygın bir uygulamadır ve aile yapısına ilişkin güçlü bir ataerkil sistemin yansımasıdır (Lindsey 2015).

Geleneksel ve toplulukçu kültürde kadınların yaş almaları daha iyi bir sosyal pozisyona geçmelerini sağlasa da diğer taraftan medya araçlarında kadının ilerlemiş yaşa sahip olması olumsuz bir durum olarak sunulmaktadır. Televizyonda yaşlı kadınlar, tüm yaşlardaki erkeklere ve genç kadınlara göre özellikle en çok izlenme saatlerinde daha az yer almakta, film ve dizi karakterlerinde yaşlı kadınlara daha fazla oranda mağdur rolü verilmektedir (Cohen 2002, Lindsey 2015) ve yaşlı kadınlar iş ortamında çalışırken değil, daha çok aile etkinliklerinde ve sosyal faaliyetlerde gösterilmektedir (Bradley ve Longino 2001). Aynı zamanda yaşlı olmanın, fiziksel çekicilik ve güzellik açısından negatif bir durum olarak sunulması her iki cinsiyet için geçerli olsa da, kadınlar için bu konudaki baskı çok daha güçlüdür. Yaşlı erkekler, özellikle olgun olmaları gibi özellikleri ön plana çıkartılarak genç kadınlar tarafından tercih edilmeye devam etseler de aynı yaştaki kadınlar, yaşlandıklarına işaret eden fiziksel özellikleri nedeniyle "çirkin" olarak algılanmaktadır (Cohen 2002). $\mathrm{Bu}$ durum elbette cinsiyetler arasındaki partner seçiminde tercih edilen özelliklerdeki farklılıklarla da ilişkilidir. Erkekler daha çok fiziksel görünüş ve gençliğe odaklanırken; kadınlar ise ekonomik güç, zekâ gibi özellikleri partner seçimi açısından daha önemli bulmaktadır (Sprecherve ark. 1994, Furnham 2009). Cinsiyetler arası tercih farklılıklarındaki bu eğilimlerin daha sonraki yaşlarda da sürdüğü görülmektedir (Schwarz ve Hassebrauck 2012). Ancak medyadaki yaşlı kadınlara ilişkin yukarıda anılan olumsuz sunum biçimleri, onların benlik saygıları açısından bir tehdit oluşturmakta ve toplumda, onlara ilişkin olumsuz tutum ve kalıpyargıların sürmesini desteklemektedir (Cohen 2002).

\section{Tartışma}

Farklı birçok disiplinde insana dair yapılan araştırmalarda cinsiyet en temel değişkenlerden biri olarak karşımıza çıkmaktadır. Biyolojik cinsiyetin ötesinde sosyal 
olarak yapılandırdığımız toplumsal cinsiyet kavramı bebeklikten ileri yaşa diğger insanlarla etkileşimimizi önemli ölçüde şekillendirmektedir. İlk yıllardan itibaren çocuklar sosyal çevreleri aracılığıyla dünyanın kadın-erkek sınıflamasının ne anlama geldiğini kavrayarak kendi cinsiyet şemalarını oluştururlar (Martin ve ark. 2002). Bu süreçte birçok toplumda yaygın olarak bulunan kadınlara ve erkeklere ilişkin kalıpyargıları da benimserler. Böylece cinsiyet şemaları çocuğu, toplumun ondan ne beklediği konusunda yönlendirmektedir (Liben ve Bigler 2002). Ayrica, bu beklentilere uygun davranmama hem evde hem okulda hem de arkadaşları ile bir arada oldukları diğer ortamlarda ciddi sosyal baskı ile sonuçlanmaktadır (Ruble ve ark. 2006). Bu baskı her iki cinsiyetten çocuk için bulunmakla birlikte son yıllarda kız çocuklarının karşılaştıkları sosyal baskıların geçmiş yüzyıllara göre azaldığını söylemek mümkündür. Buna karşın oğlan çocukları için aslında önemli bir değişiklik söz konusu değildir. Bunun güzel bir örneğini yukarıda da anıldığg gibi onlarca ülkede kız ergenlerin oğlan ergenlere göre tutarlı olarak daha eşitlikçi tutumlarına sahip olduklarını gösteren kültürlerarası çalışma ortaya koymaktadır (Dotti-Sani ve Quaranta 2017).

Cinsiyet kalıpyargıları ile mücadele edilmesi, çocukların daha sağlıklı sosyal ve duygusal gelişiminde önemli bir yere sahiptir (Stetsenko ve ark. 2000, Bhanot ve Jovanovic 2005). Çocuğun eğitiminde temel rol oynayan anne-baba ve öğretmenin yanı sıra medya içeriklerine karşı çocukların korunmaması da kalıpyargısal sosyalleştirmenin devam etmesine neden olmaktadır (Clarke-Stewart ve Parke 2014, Coyne ve ark. 2016). Cinsiyet kalıpyargıları ile mücadele edilmesinin çocukluk döneminin yanı sıra yetişkinlik dönemi için de kritik sonuçları bulunmaktadır. Günümüz yetişkinlerinin kendilerinden önceki kuşaklardan daha az cinsiyetçi olduğunu söylemek mümkündür (Chesley 2011). Kız çocukları için başlayan cinsiyet rollerindeki değişim kadınlar için de birkaç on yıldır devam etmektedir. Cinsiyet rolleri konusunda eşitlikçi yaklaşım artış göstermektedir (Carlson ve Knoester 2011). Öte yandan, kadınlar geçmişe göre iş dünyasında daha fazla yer alsalar da halen aile rollerinden temel olarak kadınların sorumlu olmaları beklenmektedir (Koivunen ve ark. 2009). Bu nedenle çok sayıda kadın, aile ve iş rollerinin çatışması nedeniyle yüksek oranda stresle mücadele etmek zorunda kalmaktadır (Poms ve ark. 2016). Aslında cinsiyet rollerine ilişkin geleneksel yaklaşım erkeklerin de yaşamlarını olumsuz etkilemekte, özellikle ekonomik açıdan onlara gereğinden fazla sorumluluk yüklemektedir (Artazcoz ve ark. 2004, Minnotte ve ark. 2010). Bu olumsuz etkilerin ileri yaşa kadar devam ettiği açıkça görülmektedir (Okamoto ve Tanaka 2004).

Cinsiyetçi kalıpyargılarla mücadele edilerek cinsiyet eşitliği sağlanması için dünyada pek çok kurum ve kuruluş tarafindan uluslararası düzeyde çalışmalar sürdürülmektedir (UNDP 2018b, United Nations 2019, UNICEF 2019) ve UNDP (2018a, 2019) tarafindan her y1l yayınlanan dünya ülkelerine ilişkin cinsiyet eşitsizliği indeksi verileri bu konuda gelişmeler olduğuna işaret etmektedir. İlgili verilere göre 2018 raporunda tüm ülkelerin \%43'ünde kadınların orta-düşük düzeyde cinsiyet eşitliğine sahip olduğu belirtilirken; 2019 raporunda bu oran \%39'a gerilemiştir. Buna karşın Türkiye'nin de içinde olduğu ülkelerin yalnızca \%33’ü cinsiyet eşitliği açısından çok yüksek insani gelişime sahiptir. Türkiye cinsiyet eşitliği 
açısından her ne kadar çok yüksek insani gelişimin olduğu ülkeler arasında yer alsa da bu ülkeler arasında kadınların işgücüne katılım oranının en düşük olduğu Suudi Arabistan ve Umman'dan sonra üçüncü ülkedir.

\section{Sonuç}

Ülkemizde Türkiye Cumhuriyeti Cumhurbaşkanlığı (2019) tarafindan yayınlanan 11. Kalkınma Planında "nitelikli insan, güçlü toplum” hedefleri arasında kadınlar için ayrı bir başlık açılmış, burada kadınlara yönelik ayrımcılıkla mücadele edilmesi, kadının ekonomik ve sosyal yaşamdaki pozisyonlarının güçlendirilmesi, medyada kadın temsilinin iyileştirilmesi, kız çocukları için eğitimde fırsat eşitliği ve fen, teknoloji, mühendislik, matematik gibi erkek egemen meslek alanlarında eğitimlerinin desteklenmesine yönelik hedefler kaleme alınmıştır. Ülkemiz bürokrasisinin en önemli belgelerinden birinde cinsiyet eşitliği ve cinsiyet kalıpyargıları ile mücade edilmesine yönelik politika kararlarının bulunması oldukça umut vericidir. Bu önemli kararların sorumlu kurum ve kuruluşlar tarafından ne kadar uygulandığının takip edilmesinin çok önemli olduğu düşünülmektedir. Bunun yanı sıra, toplumsal cinsiyet eşitsizliği kadınlarda olduğu gibi erkekler üzerinde de cinsiyetçi baskılara sebep olmaktadır. Bu baskılarla etkin bir şekilde mücadele edebilmek (örn., babaların aile rolleri ve çocuk bakımı gibi konularda daha fazla sorumluluk almalarını destekleyen politika kararlarının alınması) ve hem kadınların hem de erkeklerin cinsiyet eşitliğini içselleştirebilmelerini sağlamak için daha ileri sosyal politikalar geliştirilmelidir. $\mathrm{Bu}$ tür girişimlerde bulunmanın ülkemizi cinsiyet eşitliği konusunda daha ileri noktalara taşıyacağ1 düşünülmektedir. Bu konuda güncel ihtiyaçları ortaya koymak ve hem yetişkin hem de çocuk örnekleme yönelik müdahale çalışmalarına ve uygulamalara ş̧ık tutmak için yeterli araştırma zemininin olması önemlidir. Bu kapsamda ebeveynler ve eşler arasındaki cinsiyet kalıpyargılarının yanı sıra okul ve iş ortamında cinsiyetçi tutumlara ilişkin daha fazla görgül çalışma yapılması alanyazına önemli katkılar sağlayacaktır. Özellikle eşitlikçi ya da geleneksel cinsiyet rollerinin olduğu ailelere sahip olmanın çocuklar üzerindeki gelişimsel sonuçlarının uzun süreli boylamsal çalışmalarla incelenmesine ihtiyaç duyulmaktadır.

\section{Kaynaklar}

Allen SM, Daly K (2007) The effects of father involvement: An updated research summary of the evidence. Guelph, ON: University of Guelph, Center for Families, Work \& Well-Being.

Amuedo-Dorantes C, Kimmel J (2005) The motherhood wage gap for women in the United States: The importance of college and fertility delay. Rev Econ Househ, 3:17-48.

Antonucci TC, Akiyama H (1987) An examination of sex differences in social support among older men and women. Sex Roles, 17:737749.

Arnett JJ (2016) Human Development: A Cultural Approach, 2nd edition. London, Pearson.

Artazcoz L, Benach J, Borrell C, Cortes I (2004) Unemployment and mental health: Understanding the interactions among gender, family roles, and social class. Am J Public Health, 98:82-88.

Ashraf M (2015) Parental sexism and its relationship with daughters' sexism, self-esteem, and career aspirations (Doctoral thesis). Auckland, University of Auckland.

Austad SN (2006) Why women live longer than men: sex differences in longevity. Gend Med, 3:79-92. 
Auyeung B, Baron-Cohen S, Ashwin E, Knickmeyer R, Taylor K, Hackett G et al. (2009) Fetal testosterone predicts sexually differentiated childhood behavior in girls and in boys. Psychol Sci, 20:144-148.

Bandura A (1971) Social Learning Theory. New York, General Learning Press.

Bandura A, Bussey K (2004) On broadening the cognitive, motivational, and sociostructural scope of theorizing about gender and functioning: Comment on Martin, Ruble, and Szkrybalo. Psychol Bull, 130:691-701.

Basow SA (2006) Gender role and gender identity development. In Handbook of girls' and women's psychological health (Eds JWorell, (D Goodheart):242-251. New York, 0xford University Press.

Beard J, Biggs S, Bloom D, Fried L, Hohan P, Kalache A et al. (2012) Global Population Ageing: Peril or Promise? Geneva, World Economic Forum.

Beatty WW (1992) Gonadal hormones and sex differences in nonreproductive behaviors. In Handbook of Neurobiologyi Vol. 11. Sexual Differentiation, (Eds. AA Gerall, H Moltz, IL Ward):85-128. New York, Plenum.

Beilock SL, Gunderson EA, Ramirez G, Levine SC (2010) Female teachers' math anxiety affects girls' math achievement. Proc Natl Acad Sci U SA, 107:1860-1863.

Bem SL (1981) Gender schema theory: A cognitive account of sex typing. Psychol Rev, 88:354-364

Berk LE (2017) Development of sex differences and gender roles. In Child Development: 547-552. Noida: Pearson India Education.

Bhanot R, Jovanovic J (2005) Do parents' academic gender stereotypes influence whether they intrude on their children's homework? Sex Roles, 52:597-607.

Bigler RS, Liben LS (1992) Cognitive mechanisms in children's gender stereotyping: Theoretical and educational implications of a cognitive-based intervention. Child Dev, 63:1351-1363.

Bigler RS, Liben LS (2007) Developmental inter- group theory: Explaining and reducing children's social stereotypes and prejudice. Curr Dir Psychol Sci, 16:162-171.

Blakemore JE0 (2003) Children's beliefs about violating gender norms: Boys shouldn't look like girls, and girls shouldn't act like boys. Sex Roles, 48:411-419.

Blakemore JE0, Centers RE (2005) Characteristics of boys' and girls' toys. Sex Roles, 53:619-633.

Bouchey HA, Furman W (2006) Dating and romantic experiences in adolescence. In Blackwell Handbook of Adolescence (Eds GR Adams, Berzonsky MD):313-329. Oxford, Blackwell Publishing.

Bradley D, Longino C (2001) How older people think about images of aging in advertising and the media. Generations, 25(3):17-21. Brescoll VL, Uhlmann EL (2005) Attitudes toward traditional and non-traditional parents. Psychol Women Q, 29:436-445.

Brown SL, Nesse RM, Vinokur AD, Smith DM (2003) Providing social support may be more beneficial than receiving it: Results from a prospective study of mortality. Psychol Sci, 14:320-327.

Buhrke RA, Fuqua DR (1987) Sex differences in same- and cross-sex supportive relationships. Sex Roles, 17:339-352.

Bumpus MF, Crouter AC, McHale SM (2001) Parental autonomy granting during adolescence: exploring gender differences in context. Dev Psychol, 37:163-173.

Burleson BR (2003) The experience and effects of emotional support: What the study of cultural and gender differences can tell us about close relationships, emotion, and interpersonal communication. Pers Relatsh, 10:1-23.

Bussey K, Bandura A (1992) Self-regulatory mechanisms governing gender development. Child Dev, 63:1236-1250.

Bussey K, Bandura A (1999) Social cognitive theory of gender development and differentiation. Psychol Rev, 106:676-713

Caldwell MA, Peplau LA (1982) Sex differences in same-sex friendship. Sex Roles, 8:721-732.

Carlson DL, Knoester C (2011) Family structure and the intergenerational transmission of gender ideology. J Fam Issues, 32:709-734.

Chauhan GS, Shastri J, Mohite P (2005) Development of gender constancy in preschoolers. Psychological Studies-University of Calicut, 50:62-71.

Chesley N (2011) Stay-at-home fathers and breadwinning mothers: Gender, couple dynamics, and social change. Gend Soc, 25:642664.

Cinamon RG, Rich Y (2002) Gender differences in the importance of work and family roles: Implications for work-family conflict. Sex Roles, 47:531-541.

Clarke-Stewart A, Parke RD (2014) Social development, 2nd edition. New Jersey, Wiley.

Cohen HL (2002) Developing media literacy skills to challenge television's portrayal of older women. Educ Gerontol, 28:599-620. 
Consedine NS, Sabag-Cohen S, Krivoshekova YS (2007) Ethnic, gender, and socioeconomic differences in young adults's self-disclosure: Who discloses what and to whom? Cultur Divers Ethnic Minor Psychol, 13:254-263.

Cowan CP, Cowan PA, Heming G, Garrett E, Coysh WS, Curtis-Boles H et al. (1985). Transitions to parenthood: His, hers, and theirs. J Fam Issues, 6:451-481.

Coyne SM, Linder JR, Rasmussen EE, Nelson DA, Birkbeck V (2016) Pretty as a princess: Longitudinal effects of engagement with Disney princesses on gender stereotypes, body esteem, and prosocial behavior in children. Child Dev, 87:1909-1925.

Crouter AC, Whiteman SD, McHale SM, Osgood DW (2007) Development of gender attitude traditionality across middle childhood and adolescence. Child Dev, 78:911-926.

Datta-Gupta N, Smith N, Verner M (2008) Childcare and parental leave in the Nordic countries: A model to aspire to?, Rev Econ Househ, 6:65-89.

D'augelli AR, Hershberger SL, Pilkington NW (1998) Lesbian, gay, and bisexual youth and their families: Disclosure of sexual orientation and its consequences. Am J Orthopsychiat, 68:361-371.

Davas-Aksan HA, Ergin I, Hassoy H, Durusoy R, Çççklioğlu M (2011) Müfredata eklenen bir dersin ikinci sınıf tıp öğrencilerinin kadına yönelik şiddetle ilgili bilgi ve tutumlarına etkilerinin değerlendirilmesi. Türkiye Halk Sağlığı Dergisi, 9:144-156.

Demirdirek H, Sener Ü (2014) 81 i i için toplumsal cinsiyet eşitliği karnesi. Ankara, Türkiye Ekonomi Politikaları Araştırma Vakfı Yayınları. Dill KE, Thill KP (2007) Video game characters and the socialization of gender roles: Young people's perceptions mirror sexist media depictions. Sex Roles, 57:851-864.

Doğan T (2016) Ergenlerde ana-babaya bağlanma: Türkiye profili. Psikiyatride Güncel Yaklaşımlar, 8:406-419.

Domene JF, Arim RG, Young RA (2007) Gender and career development projects in early adolescence: Similarities and differences between mother-daughter and mother-son dyads. Qual Res Psychol, 4:107-126.

Dotti-Sani GM, Quaranta M (2017) The best is yet to come? Attitudes toward gender roles among adolescents in 36 countries. Sex Roles, 77:30-45.

Eccles JS, Freedman-Doan C, Frome P, Jacobs J, Yoon KS (2000) Gender-role socialization in the family: A longitudinal approach. In The developmental social psychology of gender (Eds T Eckes, HM Trautner):333-360. New York, Psychology Press.

Eccles JS, Jacobs JE, Harold RD (1990) Gender role stereotypes, expectancy effects, and parents' socialization of gender differences. J Soc Issues, 46:183-201.

Egan SK, Perry DG (2001) Gender identity: a multidimensional analysis with implications for psychosocial adjustment. Dev Psychol, 37:451-463.

Emmerich WN (1981) Non-monotonic trends in social cognition: The case of gender identity. In U-shaped behavioral growth, (Eds. T Eckes, HM Trautner):249-269. New York, Academic Press.

Evrenol-Öçal S (2019) Üniversite öğrencilerine yönelik geliştirilen kadına karşı her türlü düşmanca tutuma (mizojini) karşı eğitim programının etkinliğinin değerlendirilmesi (Doktora tezi). Ankara, Hacettepe Üniversitesi.

Fabes RA, Martin CL, Hanish LD, Anders MC, Madden-Derdich DA (2003) Early school competence: The roles of sex-segregated play and effortful control. Dev Psychol, 39:848-858.

Fagot BI (1985) Changes in thinking about early sex role development. Dev Rev, 5:83-98.

Farkas T, Leaper C (2014) Is having an older sister or older brother related to younger siblings' gender typing? A meta-analysis. In Current issues in developmental psychology: Gender and development (Eds PJ Leman, HR Tenenbaum):63-77. New York, Psychology Press.

Feldman HA, Longcope C, Derby CA, Johannes CB, Araujo AB, Coviello AD et al. (2002) Age trends in the level of serum testosterone and other hormones in middle-aged men: Iongitudinal results from the Massachusetts male aging study. J Clin Endocrinol Metab, 87:589598.

Fortin NM (2005) Gender role attitudes and the labour-market outcomes of women across OECD countries. Oxford Rev Econ Policy, 21:416-438.

Frank SJ, Towell PA, Huyck M (1985) The effects of sex-role traits on three aspects of psychological well-being in a sample of middleaged women. Sex Roles, 12:1073-1087.

Freedman-Doan C, Wigfield A, Eccles JS, Blumenfeld P, Arbreton A, Harold RD (2000) What am I best at? Grade and gender differences in children's beliefs about ability improvement. J Appl Dev Psychol, 21:379-402

Furnham A (2009) Sex differences in mate selection preferences. Pers Individ Differ, 47:262-267.

Gezici M (2002) Çalışan kadınların ve ev kadınlarııın benlik-algııı, benlik-kurgusu ve merkezi kimlik tanımı açısından karşılaşıııııması. (Yüksek lisans tezi). Ankara, Hacettepe Üniversitesi. 
Gibbons JL, Stiles DA, Shkodriani GM (1991) Adolescents' attitudes toward family and gender roles: An international comparison. Sex Roles, 25:625-643.

Gibson PA, Baker EH, Milner AN (2016) The role of sex, gender, and education on depressive symptoms among young adults in the United States. J Affect Disord, 189:306-313.

Giles JW, Heyman GD (2005) Young children's beliefs about the relationship between gender and aggressive behavior. Child Dev, 76:107-121.

Gorrese A, Ruggieri R (2012) Peer attachment: A meta-analytic review of gender and age differences and associations with parent attachment. J Youth Adolesc, 41:650-672.

Grey CC (2015) Huggies, high-fives, and huismannen: Exploring the masculinity and everyday experiences of Dutch stay-at-home fathers. The Netherlands, International Perspectives on Sexuality \& Gender, SIT Study Abroad.

Gunderson EA, Ramirez G, Levine SC, Beilock SL (2012) The role of parents and teachers in the development of gender-related math attitudes. Sex Roles, 66:153-166.

Gupta T, Way N, McGill RK, Hughes D, Santos C, Jia Y et al. (2013) Gender-typed behaviors in friendships and well-being: A crosscultural study of Chinese and American boys. J Adolesc, 23:57-68

Halim MLD, Gutierrez BC, Bryant DN, Arredondo M, Takesako K (2018) Gender is what you look like: Emerging gender identities in young children and preoccupation with appearance. Self Identity, 17:455-466.

Hall CM, Jones JA, Meyer-Bahlburg HF, Dolezal C, Coleman M, Foster P et al. (2004) Behavioral and physical masculinization are related to genotype in girls with congenital adrenal hyperplasia. J Clin Endocrinol Metab, 89:419-424.

Hargreaves DA, Tiggemann M (2004) Idealized media images and adolescent body image:"Comparing" boys and girls. Body Image, 1:351-361.

He W, Goodkind D, Kowal PR (2016) An aging world: 2015. International Population Reports. Washington DC, US Census Bureau.

Hilliard LJ, Liben LS (2010) Differing levels of gender salience in preschool classrooms: Effects on children's gender attitudes and intergroup bias. Child Dev, 81:1787-1798.

Hines M, Brook C, Conway GS (2004) Androgen and psychosexual development: Core gender identity, sexual orientation, and recalled childhood gender role behavior in women and men with congenital adrenal hyperplasia (CAH). J Sex Res, 41:75-81.

Hoffman LW (2000) Maternal employment: Effects of social context. In Resilience across contexts: Family, work, culture, and community (Eds RD Taylor, MC Wang):147-176. Mahwah, NJ, Erlbaum.

Hoffnung M (2004) Wanting it all: Career, marriage, and motherhood during college-educated women's 20s. Sex Roles, 50:711-723.

Holmes-Lonergan HA (2003) Preschool children's collaborative problem-solving interactions: The role of gender, pair type, and task. Sex Roles, 48:505-517.

Hong ZR, Veach PM, Lawrenz F (2003) An investigation of the gender stereotyped thinking of Taiwanese secondary school boys and girls. Sex Roles, 48:495-504.

Jacobs JE, Weisz V (1994) Gender stereotypes: Implications for gifted education. Roeper Rev, 16:152-155.

Johnson B, Leibowitz S, Chavez A, Herbert SE (2019) Risk versus resiliency: Addressing depression in lesbian, gay, bisexual, and transgender youth. Child Adolesc Psychiatr Clin N Am, 28:509-521.

Kalmijn M (1999) Father involvement in childrearing and the perceived stability of marriage. J Marriage Fam, 61:409-421.

Katz-Wise SL, Priess HA, Hyde JS (2010) Gender-role attitudes and behaviour across the transition to parenthood. Dev Psychol, 46:1828.

Kaufman G (2000) Do gender role attitudes matter? Family formation and dissolution among traditional and egalitarian men and women. J Fam Issues, 21:128-144.

Kaufman G, Taniguchi H (2006) Gender and marital happiness in later life. J Fam Issues, 27:735-757.

King TL, Kavanagh A, Scovelle AJ, Milner A (2020) Associations between gender equality and health: a systematic review. Health Promot Int, 35:27-41.

Kling KC, Hyde JS, Showers CJ, Buswell BN (1999) Gender differences in self-esteem: A meta-analysis. Psychol Bull, 125:470-500.

Koivunen JM, Rothaupt JW, Wolfgram SM (2009) Gender dynamics and role adjustment during the transition to parenthood: Current perspectives. Fam J Alex Va, 17:323-328.

Kramer KZ, Kelly EL, McCulloch JB (2015) Stay-at-home fathers: Definition and characteristics based on 34 years of CPS data. J Fam Issues, 36:1651-1673. 
Kramer KZ, Kramer A (2016) At-home father families in the United States: Gender ideology, human capital, and unemployment. J Marriage Fam, 78:1315-1331.

Kroger J (2006) Identity development during adolescence. In Blackwell Handbook of Adolescence (Eds GR Adams, MD Berzonsky): 205-226. Oxford, Blackwell Publishing.

Kuru AG (2016) Türk ailesinde karakter ve otorite: Bir toplumsal tip olarak kaynana ve kaynanalık rolü üzerine bir araştırma (Yüksek lisans tezi). Konya, Selçuk Üniversitesi.

Lackey PN (1989) Adults' attitudes about assignments of household chores to male and female children. Sex Roles, 20:271-281.

Lamb ME (2000) The history of research on father involvement. Marriage Fam Rev, 29:23-42.

Latshaw BA, Hale SI (2016) 'The domestic handoff': stay-at-home fathers'time-use in female breadwinner families. J Fam Stud, 22:97120.

Lauer JE, Ilksoy SD, Lourenco SF (2018) Developmental stability in gender-typed preferences between infancy and preschool age. Dev Psychol, 54:613-620.

Laursen B, Collins WA (2004) Parent-child communication during adolescence. In Handbook of Family Communication (Ed AL Vangelisti):333 - 348. New Jersey, Erlbaum.

Leaper C (2013) Gender development during childhood. In The Oxford Handbook of Developmental Psychology (Ed PD Zelazo): 327377. New York, Oxford University Press.

Leaper C, Anderson KJ, Sanders P (1998) Moderators of gender effects on parents' talk to their children: A meta-analysis. Dev Psychol, 34:3-27.

Leaper C, Friedman CK (2007) The socialization of gender. In Handbook of Socialization: Theory and Research (Eds JE Grusec, PD Hastings):561-587. New York, Guilford Press.

Leaper C, Smith TE (2004) A meta-analytic review of gender variations in children's language use: Talkativeness, affliative speech, and assertive speech. Dev Psychol, 40:993-1027.

Lefkowitz ES, Zeldow PB (2006) Masculinity and femininity predict optimal mental health: A belated test of the androgyny hypothesis. J Pers Assess, 87:95-101.

Leinbach MD, Hort BE, Fagot BI (1997) Bears are for boys: Metaphorical associations in young children's gender stereotypes. Cogn Dev, 12:107-130.

Leman PJ, Ahmed S, Ozarow L (2005) Gender, gender relations, and the social dynamics of children's conversations. Dev Psychol, 41:64-74.

Lephart ED, Call SB, Rhees RW, Jacobson NA, Scott-Weber K, Bledsoe J et al. (2001) Neuroendocrine regulation of sexually dimorphic brain structure and associated sexual behavior in male rats is genetically controlled. Biol Reprod, 64:571-578.

Levitt HM (2019) A psychosocial genealogy of LGBTQ+ gender: An empirically based theory of gender and gender identity cultures. Psychol Women Q, 43:275-297.

Levy GD, Taylor MG, Gelman SA (1995) Traditional and evaluative aspects of flexibility in gender roles, social conventions, moral rules, and physical laws. Child Dev, 66:515-531.

Liben LS, Bigler RS (2002) The developmental course of gender differentiation: conceptualizing, measuring, and evaluating constructs and pathways. Monogr Soc Res Child Dev, 67:148-183.

Liben LS, Signorella ML (1993) Gender-schematic processing in children: The role of initial interpretations of stimuli. Dev Psychol, 29:147-183

Lindsey LL (2015) Gender roles: A sociological perspective, 6th edition. New York, Routledge.

Livson FB (1983) Gender identity: A life-span view of sex-role development. In Sexuality in the Later Years: Roles and Behavior (Ed RB Weg):105-127. New York, Academic Press.

Lye DN, Biblarz TJ (1993) The effects of attitudes toward family life and gender roles on marital satisfaction. J Fam Issues, 14:157-188. Maccoby EE (1998) The two sexes: Growing up apart, coming together. Cambridge, MA, Harvard University Press.

Marshall TC (2010) Gender, peer relations, and intimate romantic relationships. In Handbook of Gender Research in Psychology, Vol. 2. Gender Research in Social and Applied Psychology (Eds JC Chrisler, DR McCreary): 281-310. New York, Springer

Martin CL (1990) Attitudes and expectations about children with nontraditional and traditional gender roles. Sex Roles, 22:151-164. Martin CL, Dinella L (2001) Gender related development. In International Encyclopedia of the Social and Behavioral Sciences (Eds N Smelser, P Baltes):6020-6027. New York, Elsevier. 
Martin CL, Fabes RA (2001) The stability and consequences of young children's same-sex peer interactions. Dev Psychol, 37:431-446. Martin CL, Fabes RA, Hanish L, Leonard S, Dinella LM (2011) Experienced and expected similarity to same-gender peers: Moving toward a comprehensive model of gender segregation. Sex Roles, 65:421-434.

Martin CL, Halverson CF (1981) A schematic processing model of sex typing and stereotyping in children. Child Dev, 52:1119-1134.

Martin CL, Halverson CF (1987) The roles of cognition in sex role acquisition. In Current Conceptions of Sex Roles and Sex Typing: Theory and Research (Ed DB Carter):123-137. New York, Praeger.

Martin CL, Ruble D (2004) Children's search for gender cues: Cognitive perspectives on gender development. Curr Dir Psychol Sci, 13:67-70.

Martin CL, Ruble DN, Szkrybalo J (2002) Cognitive theories of early gender development. Psychol Bull, 128:903-933.

Masterson CR, Hoobler JM (2015) Care and career: A family identity-based typology of dual-earner couples. J Organ Behav, 36:75-93. Mattingly MJ, Bianchi SM (2003) Gender differences in the quantity and quality of free time: The U.S. experience. Soc Forces, 81:9991030.

Maume DJ (2016) Can men make time for family? Paid work, care work, work-family reconciliation policies, and gender equality. Soc Curr, 3:43-63.

McCabe MP, Ricciardelli LA (2001) Parent, peer and media influences on body image and strategies to both increase and decrease body size among adolescent boys and girls. Adolescence, 36:225-240.

McGinn KL, Ruiz-Castro M, Lingo EL (2015) Mums the word! Cross-national effects of maternal employment on gender inequalities at work and at home. Harvard Business School Working Paper, No. 15-094.

McHale SM, Crouter AC, Whiteman SD (2003) The family contexts of gender development in childhood and adolescence. Soc Dev, 12:125-148.

McHale SM, Updegraff KA, Helms-Erikson H, Crouter AC (2001) Sibling influences on gender development in middle childhood and early adolescence: A longitudinal study. Dev Psychol, 37:115-125

Mehta CM, Strough J (2010) Gender segregation and gender-typing in adolescence. Sex Roles, 63:251-263.

Melendez JC, Mayordomo T, Sancho P, Tomas JM (2012) Coping strategies: Gender differences and development throughout life span. Span J Psychol, 15:1089-1098.

Mesman J, Groeneveld MG (2018) Gendered parenting in early childhood: Subtle but unmistakable if you know where to look. Child Dev Perspect, 12:22-27.

Milkie MA, Peltola P (1999) Playing all the roles: Gender and the work-family balancing act. J Marriage Fam, 61:476-490.

Minnotte KL, Minnotte MC, Pedersen DE, Mannon SE, Kiger G (2010) His and her perspectives: Gender ideology, work-to-family conflict, and marital satisfaction. Sex Roles, 63:425-438.

Money J (1973). Gender role, gender identity, core gender identity: Usage and definition of terms. J Am Acad Psychoanal, 1:397-402. Morrow DF (2004) Social work practice with gay, lesbian, bisexual, and transgender adolescents. Fam Soc, 85:91-99.

Munroe RL, Romney AK (2006) Gender and age differences in same-sex aggregation and social behavior: A four-culture study. J Cross Cult Psychol, 37:3-19.

Nosek BA, Smyth FL, Sriram N, Lindner NM, Devos T, Ayala A et al. (2009) National differences in gender-science stereotypes predict national sex differences in science and math achievement. Proc Natl Acad Sci U S A, 106:10593-10597.

Okamoto K, Tanaka Y (2004) Gender differences in the relationship between social support and subjective health among elderly persons in Japan. Prev Med, 38:318-322.

Öngen D (2004) Özerklik kazanma sürecinde ergen-anne ile ergen-baba ilişkileri arasındaki farkıııklar. Eğitim ve Bilim, 29(131):3-13. Oshio T, Nozaki K, Kobayashi M (2013) Division of household labor and marital satisfaction in China, Japan, and Korea. J Fam Econ Issues, 34:211-223.

Ostan R, Monti D, Gueresi P, Bussolotto M, Franceschi C, Baggio G (2016) Gender, aging and longevity in humans: an update of an intriguing/neglected scenario paving the way to a gender-specific medicine. Clin Sci, 130:1711-1725.

Özonur-Çöloğlu D (2009) Bir üçlemeyi, "modern-geleneksel ve kadın-erkek" karşıtlığında yeniden okumak: gelin, düğün, diyet. Selçuk İletişim Dergisi, 6:144-153.

Paçacıoğu B (2018) Üç farkı kuşaktaki evli kadın ve erkeklerin toplumsal cinsiyet rollerine ilişkin tutumları ile aile işlevleri arasındaki ilişki (Doktora tezi). Ankara, Hacettepe Üniversitesi.

Peake A, Harris KL (2002) Young adults' attitudes toward multiple role planning: The influence of gender, career traditionality, and 
marriage plans. JVocat Behav, 60:405-421.

Piaget J, Inhelder B (1969) The psychology of the child. New York, Basic Books.

Pinquart M, Sörensen S (2001) Gender differences in self-concept and psychological well-being in old age: A meta-analysis. J Gerontol B Psychol Sci Soc Sci, 56:P195-P213.

Pomerantz EM, Dong W (2006) Effects of mothers' perceptions of children's competence: The moderating role of mothers' theories of competence. Dev Psychol, 42:950-961.

Poms LW, Fleming LC, Jacobsen KH (2016) Work-family conflict, stress, and physical and mental health: a model for understanding barriers to and opportunities for women's well-being at home and in the workplace. World Med Health Policy, 8:444-457.

Poulin-Dubois D, Serbin LA, Eichstedt JA, Sen MG, Beissel CF (2002) Men don't put on make-up: Toddlers' knowledge of the gender stereotyping of household activities. Soc Dev, 11:166-181.

Priess HA, Lindberg SM, Hyde JS (2009) Adolescent gender-role identity and mental health: Gender intensification revisited. Child Dev, 80:1531-1544.

Rafferty J, AAP Committee on Psychosocial Aspects of Child and Family Health, AAP Committee on Adolescence, AAP Section on Lesbian, Gay, Bisexual, and Transgender Health and Wellness (2018) Ensuring comprehensive care and support for transgender and gender-diverse children and adolescents. Pediatrics, 142(4):e20182162.

Ridgeway CL, Bourg C (2004) Gender as status: An expectation states theory approach. In The Psychology of Gender (Eds AL Eagly, AE Beall, RJ Sternberg):217-241. New York, Guilford Press.

Rochlen AB, McKelley RA, Suizzo MA, Scaringi V (2008) Predictors of relationship satisfaction, psychological well-being, and life satisfaction among stay-at-home fathers. Psychol Men Masc, 9:17-28.

Rosenberg M, Jellinek MS (2002) Children with gender identity issues and their parents in individual and group treatment. J Am Acad Child Adolesc Psychiatry, 41:619-621.

Ruble DN, Martin CL (1998) Gender development. In Handbook of Child Psychology, Vol. 3 (Eds W Damon, N Eisenberg):993-1016. New York, Wiley.

Ruble DN, Martin CL, Berenbaum SA (2006) Gender development. Handbook of Child Psychology (Vol 3): Social, Emotional, and Personality Development (Eds N Eisenberg, W Damon, RM Lerner): 858-931). Haboken, NJ, Wiley.

Ruble DN, Taylor LJ, Cyphers L, Greulich FK, Lurye LE, Shrout PE (2007) The role of gender constancy in early gender development. Child Dev, 78:1121-1136.

Rust J, Golombok S, Hines M, Johnston K, Golding J, ALSPAC Study Team (2000) The role of brothers and sisters in the gender development of preschool children. J Exp Child Psychol, 77:292-303.

Sanchez L, Thomson E (1997) Becoming mothers and fathers: Parenthood, gender, and the division of labor. Gend Soc, 11:747-772.

Sato T, Matsumoto T, Kawano H, Watanabe T, Uematsu Y, Sekine K et al. (2004) Brain masculinization requires androgen receptor function. Proc Natl Acad Sci U S A, 101:1673-1678.

Schwarz S, Hassebrauck M (2012) Sex and age differences in mate-selection preferences. Hum Nat, 23:447-466.

Sell RL (1997) Defining and measuring sexual orientation: A review. Arch Sex Behav, 26:643-658.

Serbin LA, Powlishta KK, Gulko J, Martin CL, Lockheed ME (1993) The development of sex typing in middle childhood. Monogr Soc Res Child Dev, 58:1-95.

Servin A, Nordenström A, Larsson A, Bohlin G (2003) Prenatal androgens and gender-typed behavior: A study of girls with mild and severe forms of congenital adrenal hyperplasia. Dev Psychol, 39:440-450.

Shapiro JR, Williams AM (2012) The role of stereotype threats in undermining girls' and women's performance and interest in STEM fields. Sex Roles, 66:175-183.

Sheldon P (2013) Examining gender differences in self-disclosure on Facebook versus face-to-face. Soc Media Soc, 2:88-105.

Simons L, Schrager SM, Clark LF, Belzer M, Olson J (2013) Parental support and mental health among transgender adolescents. J Adolescent Health, 53:791-793.

Slaby RG, Frey KS (1975) Development of gender constancy and selective attention to same-sex models. Child Dev, 46:849-856.

Sprecher S, Sullivan Q, Hatfield E (1994) Mate selection preferences: gender differences examined in a national sample. J Pers Soc Psychol, 66:1074-1080.

Sravanti L, Sagar JVK (2019) Gender identity: Emergence in preschoolers. Journal of Psychosexual Health, 1:286-287. 
Steffens MC, Jelenec P, Noack P (2010) On the leaky math pipeline: Comparing implicit math-gender stereotypes and math withdrawal in female and male children and adolescents. J Educ Psychol, 102:947-963.

Stern M, Karraker KH (1989) Sex stereotyping of infants: A review of gender labeling studies. Sex Roles, 20:501-522

Stetsenko A, Little TD, Gordeeva T, Grasshof M, Oettingen G (2000) Gender effects in children's beliefs about school performance: A cross-cultural study. Child Dev, 71:517-527.

Stoneman Z, Brody GH, MacKinnon CE (1986) Same-sex and cross-sex siblings: Activity choices, roles, behavior, and gender stereotypes. Sex Roles, 15:495-511.

Sultan S, Chaudry H (2008) Gender-based differences in the patterns of emotional self-disclosure. Pakistan Journal of Psychological Research, 23:107-122.

Swenson LP, Rose AJ (2009) Friends'knowledge of youth internalizing and externalizing adjustment: Accuracy, bias, and the influences of gender, grade, positive friendship quality, and self-disclosure. J Abnorm Child Psychol, 37:887-901.

Taylor M (2005) Young adult perceptions of egalitarianism in their families of origin: An examination of conflict style, locus of control, and psychological distress in young adult relationships (Doctoral thesis). Arizona, The University of Arizona.

Taylor M, Segrin C (2010) Perceptions of parental gender roles and conflict styles and their association with young adults' relational and psychological well-being. Commun Res Rep, 27:230-242.

Temiz Z, Cin FM (2017). Okul öncesi eğitimde cinsiyet eşitliği üzerine betimsel bir çalışma. Yüzüncü Yıl Üniversitesi Eğitim Fakültesi Dergisi, 14:940-965.

Tenenbaum HR, Ford S, Alkhedairy B (2011) Telling stories: Gender differences in peers' emotion talk and communication style. Br J Dev Psychol, 29:707-721.

Tenenbaum HR, Leaper C (2003) Parent-child conversations about science: The socialization of gender inequities?. Dev Psychol, 39:34-47.

Tenenbaum HR, May D (2014) Gender in parent-child relationships. In Current Issues in Developmental Psychology: Gender And Development (Eds PJ Leman HR Tenenbaum):1-19. New York, Psychology Press.

Tepper CA, Cassidy KW (1999) Gender differences in emotional language in children's picture books. Sex Roles, 40:265-280.

Thompson SK (1975) Gender labels and early sex role development. Child Dev, 46:339-347.

Tiggemann M, Slater A (2013) NetGirls: The Internet, Facebook, and body image concern in adolescent girls. Int J Eat Disord, 46:630633.

Tsuboi H, Hirai H, Kondo K (2016) Giving social support to outside family may be a desirable buffer against depressive symptoms in community-dwelling older adults: Japan gerontological evaluation study. Biopsychosoc Med, 10:18.

TÜIK (2019) Haber Bülteni: İşü̈cü istatistikleri, Şubat 2018. Ankara, Türkiye İstatistik Kurumu.

TÜiK (2020) Nüfus İstatistikleri: Yıllara, Yaş Grubu ve Cinsiyete Göre Nüfus, Genel Nüfus Sayımları. Ankara, Türkiye İstatistisk Kurumu.

Tuncer M, Şen BG (2018) Okul öncesi eğitimde toplumsal cinsiyet eşitliğine yönelik Türkiye'de yapılan çalısmalar. Avrasya Sosyal ve Ekonomi Araştırmaları Dergisi, 5:870-882.

Türkiye Cumhuriyeti Cumhurbaşkanlığı (2019) On Birinci Kalkınma Planı (2019-2023). Ankara, TC Cumhurbşkanlığı.

Turner PJ, Gervai J (1995) A multidimensional study of gender typing in preschool children and their parents: Personality, attitudes, preferences, behavior, and cultural differences. Dev Psychol, 31:759-772.

Turner-Bowker DM (1996) Gender stereotyped descriptors in children's picture books: Does "Curious Jane" exist in the literature? Sex Roles, 35:461-488.

UNDP, United Nations Development Programme (2018a) Human Development Reports: Gender Inequality Index. New York, United Nations.

UNDP, United Nations Development Programme (2018b) UNDP Gender Equality Strategy: 2018-2021. New York, United Nations.

UNDP, United Nations Development Programme (2019) Human Development Reports: Gender Inequality Index. New York, United Nations.

UNICEF, United Nations Children's Fund (2019) Annual Report 2018. New York, UNICEF.

United Nations (2019). Annual Report: 2019. New York, United Nations.

Vafaei A, Ahmed T, Freire ADNF, Zunzunegui MV, Guerra RO (2016) Depression, sex and gender roles in older adult populations: The International Mobility in Aging Study (IMIAS). PloS one, 11:e0146867.

Vafaei A, Alvarado B, Tomás C, Muro C, Martinez B, Zunzunegui MV (2014) The validity of the 12-item Bem Sex Role Inventory in older Spanish population: An examination of the androgyny model. Arch Gerontol Geriatr, 59:257-263. 
Vandervoort D (2000) Social isolation and gender. Curr Psychol, 19:229-236.

Vogel DA, Lake MA, Evans S, Karraker KH (1991) Children's and adults'sex-stereotyped perceptions of infants. Sex Roles, 24:605-616.

Volkom MV (2003) The relationships between childhood tomboyism, siblings' activities, and adult gender roles. Sex Roles, 49:609618.

Watkins D, Lam MK, Regmi M (1991) Cross-cultural assessment of self-esteem: A Nepalese investigation. Psychologia, 34:98-108.

Weger H, Emmett MC (2009) Romantic intent, relationship uncertainty, and relationship maintenance in young adults' cross-sex friendships. J Soc Pers Relat, 26:964-988.

Weisner TS, Garnier H, Loucky J (1994) Domestic tasks, gender egalitarian values and children's gender typing in conventional and nonconventional families. Sex Roles, 30:23-54.

WHO (World Health Organization) (2002) Gender and Health. Geneva, WHO

Willerth M, Ahmed T, Phillips SP, Pérez-Zepeda MU, Zunzunegui MV, Auais M (2020) The relationship between gender roles and selfrated health: A perspective from an international study. Arch Gerontol Geriatr, 87:103994.

Wiseman CV, Sunday SR, Becker AE (2005) Impact of the media on adolescent body image. Child Adolesc Psychiatr Clin N Am, 14:453471.

YıImaz A (2004) Türk kültüründe kadın. Milli Folklor, 16:111-123.

Yüksel-Sahin F, Öztoprak Ö (2019) Ergenlerin sosyal medya bağımllı̆̆ıı düzeylerinin benlik saygısına göre incelenmesi. IBAD Sosyal Bilimler Dergisi, (Özel Sayı):363-377.

Yunger JL, Carver PR, Perry DG (2004) Does gender identity influence children's psychological well-being?. Dev Psychol, 40:572-582.

Zahidi S (2012) Women and ageing. In Global Population Ageing: Peril or Promise? (Eds J Beard, S Biggs, D Bloom, L Fried, P Hohan, A Kalache, J Olshansky):21-24). Cologny, World Economic Forum.

Yazarların Katkıları: Yazarlara çalışmaya önemli bir bilimsel katkı sağladıklarııı ve makalenin hazıllanmasında veya gözden geçirilmesinde yardımcı olduklarını kabul etmişlerdir.

Danışman Değerlendirmesi: Dış bağımsız.

Çıkar Çatışması: Yazarlar çıkar çatışması bildirmemiştir.

Finansal Destek: Yazarlar bu çalışma için finansal destek almadıklarııı beyan etmişlerdir.

Authors Contributions: The authors attest that they made an important scientific contribution to the study and have assisted with the drafting or revising of the manuscript.

Peer-review: Externally peer-reviewed.

Conflict of Interest: No conflict of interest was declared by the authors.

Financial Disclosure: The authors declared that this study has received no financial support. 